\title{
A novel approach to determine post mortem interval using neutron radiography
}

Hassina Z. Bilheux ${ }^{\mathrm{a}, 1,{ }^{*}}$, Maria Cekanova ${ }^{\mathrm{b}, 1}$, Arpad A. Vass ${ }^{\mathrm{c}}$, Trent L. Nichols ${ }^{\mathrm{d}}$, Jean C. Bilheux ${ }^{\mathrm{e}}$, Robert L. Donnell ${ }^{\mathrm{f}}$, Vincenzo Finochiarro ${ }^{\mathrm{g}}$

${ }^{a}$ Chemical and Engineering Materials Division, Oak Ridge National Laboratory, Oak Ridge, TN 37831

${ }^{\mathrm{b}}$ Department of Small Animal Clinical Sciences, College of Veterinary Medicine, The University of Tennessee, Knoxville, TN 37996

${ }^{\mathrm{c}}$ Biosciences Division, Oak Ridge National Laboratory, Oak Ridge, TN 37831

${ }^{\mathrm{d}}$ Measurement Science and Systems Engineering Division, Oak Ridge National Laboratory, Oak Ridge, TN 37831

${ }^{\mathrm{e}}$ Neutron Data Analysis and Visualization Division, Oak Ridge National Laboratory, Oak Ridge, TN 37831

${ }^{\mathrm{f}}$ Department of Biomedical and Diagnostic Sciences, College of Veterinary Medicine, The University of Tennessee, Knoxville, TN 37996

${ }^{\mathrm{g}}$ Department of Matter Physics and Electronic Engineering, University of Messina, Messina, Italy

${ }^{1} \mathrm{HZB}$ and MC contributed equally to this work.

*Corresponding author's information:

Dr. Hassina Z. Bilheux,

Oak Ridge National Laboratory

Spallation Neutron Source

Building 8600, Rm B-440

P.O. Box 2008, MS 6475

Oak Ridge, TN 37831-6475

email: bilheuxhn@ornl.gov

Tel: (865) 384-9630 


\begin{abstract}
One of the most difficult challenges in forensic research is to objectively determine the post-mortem interval (PMI). The accuracy of PMI is critical for determining the timeline of events surrounding a death. Most PMI techniques rely on gross morphological changes of cadavers that are highly sensitive to taphonomic factors. Recent studies have demonstrated that even exhumed individuals exposed to the same environmental conditions with similar PMIs can present as different stages of decomposition.

After death, tissue undergoes sequential changes consisting of organic and inorganic phase variations, as well as a gradual reduction of tissue water content. Hydrogen $(\mathrm{H})$ is the primary contributor to neutron radiography (NR) contrast in biological specimens because (1) it is the most abundant element in biological tissues and (2) its nucleus scatters thermal and cold neutrons more strongly than any other atomic nucleus. These contrast differences can be advantageous in a forensic context to determine small changes in hydrogen concentrations.

Neutron radiography of decaying canine tissues was performed to evaluate the PMI by measuring the changes in $\mathrm{H}$ content. In this study, dog cadavers were used as a model for human cadavers. Canine tissues and cadavers were exposed to controlled (laboratory settings) and uncontrolled (University of Tennessee Anthropology Research Facility) environmental conditions, respectively. Neutron radiographs were supplemented with photographs and histology data to assess the decompositional stages of cadavers. Results demonstrated that the increase in neutron transmission likely corresponded to a decrease in hydrogen content in the tissue, which was correlated with the decay time of the tissue. Tissues depleted in hydrogen are brighter in the neutron transmission radiographs of skeletal muscles, lung, and bone, under controlled conditions. Over a period of 10 days, changes in neutron transmission through lung and muscle were found to be higher than bone by $8.3 \%, 7.0 \%$, and $2.0 \%$, respectively. Results measured during uncontrolled conditions were harder to assess and further studies are necessary. In conclusion, neutron radiography may be used to detect changes in hydrogen abundance that can be correlated with the post-mortem interval.
\end{abstract}

Keywords: post-mortem interval, skeletal muscle, bone, lung, neutron radiography, hydrogen content, canine tissue

\title{
1. Introduction
}

Determination of an accurate post mortem interval (PMI) is one of the most complex tasks in death scene investigations. PMI depends on a series of complex exogenous parameters such as environmental conditions, soil characteristics, scavengers and insect activities at the burial site, but also endogenous conditions such as body build, cause of death and use of drugs. Human decomposition begins approximately a few minutes after death. The onset of decomposition is governed by a process called autolysis - or self-digestion and begins a few minutes after death. As cells of the body are deprived of oxygen, carbon dioxide in the blood increases, $\mathrm{pH}$ decreases, and metabolites accumulate, which further modify normal cellular function. Concomitantly, cellular enzymes (lipases, proteases, etc.) begin to digest the cells from the inside out which eventually causes them to rupture and release nutrient-rich fluids. Autolysis usually does not become visually apparent for a few days [1-3].

Muscles are primarily composed of proteins, which in general break down into amino acids by proteolysis and hydrogen sulphide gas, pyruvic acid, thiols, and ammonia after bacterial decomposition. In addition to protein, muscles contain fat that is degraded into fatty acids and glycerol by lipases. Free fatty acids are further degraded anaerobically through hydrogenation by bacterial enzymes (whereby the hydrogen content is increased by transforming unsaturated bonds into single bonds) or in aerobic environmental conditions via oxidation to produce peroxide linkages in fatty acids eventually producing aldehydes and ketones. These different conditions of decomposition affect the amount of hydrogen content that needs to be further evaluated.

There are currently few scientific methods based on chemical measurements that can be used to provide an accurate PMI [4-6]. Typically, such information is gained through the cooperation of trained forensic scientists who provide information based on experience. For example, estimating the PMI prior to the onset of putrefaction (36-72 hrs) generally involves visual inspection of the body by observing the appearance (i.e. rigor and livor mortis) and determining the core body temperature and gastric contents [7,8]. Several techniques have been used to estimate PMI such as vitreous humor potassium concentration $[9,10]$, volatile 
fatty acids for pre-skeletonized remains during putrefaction, odor mortis and biochemical markers [10-13]. Forensic entomology is another useful tool that has gained success in determining PMI [14-17]. Along with decompositional by-products, forensic entomology is currently one of the most commonly used techniques to determine PMI. While these methods cover the entire breadth of human decomposition, from early $(<12$ hours) to very late (skeletonized $>10$ years), many PMI determinations are still highly problematic due to their large error ranges.

The principle of neutron imaging [18-21] is based on the attenuation, both scattering and absorption, of a directional neutron beam by the matter through which it passes. Neutron imaging is complementary to X-ray and magnetic resonance imaging (MRI). X-rays are scattered and absorbed by the electrons (i.e. the attenuation increases monotonically with atomic number), and are not sensitive to light elements such as $\mathrm{H}$. Neutrons interact with atomic nuclei, and their attenuation does not scale in a regular way with atomic number. The neutron imaging technique is based on the strong attenuation of neutrons by $\mathrm{H}$ (the predominant elemental constituent of biological materials), which is manifest as contrast in an image [22,23].

The decomposition of dog cadavers is a suitable model for human tissue decomposition [24]. In this study, changes in $\mathrm{H}$ content in decomposing canine skeletal muscles, lungs, small bones were evaluated using neutron radiography under controlled laboratory. Decay studies of canine cadavers (skeletal muscles) were also conducted during uncontrolled environmental conditions (winter and summer) at the University of Tennessee Anthropology Research Facility (UTARF) of the UT Forensic Anthropology Research Center. Observations of the stage of decomposition of the dog cadavers were also recorded during both winter and summer seasons using photography and histology. Estimation of the PMI was calculated from a natural logarithmic fitting of the NR data.

\section{Material and methods}

\subsection{Experimental design}

Medium size male dog cadavers (with a weight ranging from 17 to $30 \mathrm{~kg}$ ) of different breeds such as labrador and pit bull, with no apparent sickness were obtained from the animal control agency after humane euthanasia due to the inability of the shelter to secure adequate long-term care or adoption. None of the animals were euthanized for the purpose of this study. The selection of the carcasses was independent of the sex, breed and age of the dogs. Two sets of experiments were performed:

Controlled environmental conditions: Canine cadavers were brought to the University of Tennessee College of Veterinary Medicine (UTCVM) necropsy facility a day before the first neutron imaging measurements. Resected skeletal muscle tissues were dissected into $2 \mathrm{~cm}$ x $2 \mathrm{~cm}$ x $2 \mathrm{~mm}$ thick sections (five tissue replicates), wrapped in Aluminum ( $\mathrm{Al}$ ) foil, and stored in a $4{ }^{\circ} \mathrm{C}$ refrigerator before being transported on ice to the Oak Ridge National Laboratory (ORNL) High Flux Isotope Reactor (HFIR) for neutron radiography. Bones and lung tissues were also extracted for neutron radiography assessment. Bones were manually cleaned of any tissue using scalpels. Lungs were delicately removed from the cadaver, then immediately cut using a microtome. Upon arrival at the neutron facility, tissues were kept under constant conditions $\left(22{ }^{\circ} \mathrm{C}+/-2{ }^{\circ} \mathrm{C}\right.$ and $\sim 50-60 \%$ humidity) and were exposed a few minutes to neutrons at regular time intervals over several days.

Uncontrolled environmental conditions: Canine cadavers were placed on the ground of the UTARF, in the shade of a tree and with a protective net to minimize scavenger activities, during the winter of 2011 and the summer of 2012. Temperature and humidity information in Knoxville, TN were obtained from the Biosystems Engineering Department of the Institute of Agriculture at the University of Tennessee [25]. The sites for canine cadavers were chosen away from human cadavers to prevent cross-contamination between canine and human remains. During winter, one dog cadaver was placed at the ARF on the first day of the neutron radiography measurements (Day 0 or December 7 2011). During summer, four dog cadavers were brought to the UTARF at week: six, four, and two prior to the neutron measurements. The fourth cadaver was placed at the facility on the first day (Day 0 or June 18 2012) of the experimental neutron measurements. Photographs of the dog cadavers at the UTARF were collected to monitor decay changes. Timeline of the experiments, along with date of necropsy sampling and photographs are summarize in Table 1. 
Table 1. Summary of data sampling (necropsy and photographs) for the winter and summer experiments, respectively.

\begin{tabular}{|l|c|l|l|l|}
\hline Experiment & Dog \# & Date of placement at the ARF & Photographs & Dates of tissue extraction \\
\hline & & & & \\
Winter 2011 & 1 & $\begin{array}{l}\text { Day 0 (December 7, 2011) or the first } \\
\text { day of the neutron radiographs }\end{array}$ & Day 0 and Day 2 2 & $\begin{array}{l}\text { First day and subsequently every } \\
\text { day, up to ten days }\end{array}$ \\
\hline
\end{tabular}

\begin{tabular}{|l|c|l|l|l|}
\hline Experiment & Dog \# & Date of placement at the ARF & Photographs & Dates of tissue extraction \\
\hline $\begin{array}{l}\text { Summer } \\
2012\end{array}$ & 1 & $\begin{array}{l}\text { Day -41 (six weeks prior to the first } \\
\text { neutron radiographs) }\end{array}$ & $\begin{array}{l}\text { None, cadaver } \\
\text { was completely } \\
\text { decomposed (no } \\
\text { tissue left) }\end{array}$ & N/A \\
\hline & 2 & $\begin{array}{l}\text { Day -27 (four weeks prior to the first } \\
\text { neutron radiographs) }\end{array}$ & $\begin{array}{l}\text { Photograph } \\
\text { taken after 4 } \\
\text { weeks of } \\
\text { decomposition }\end{array}$ & N/A \\
\hline $\begin{array}{l}\text { Summer } \\
2012\end{array}$ & 3 & $\begin{array}{l}\text { Day -13 (two weeks prior to the first } \\
\text { neutron radiographs) }\end{array}$ & $\begin{array}{l}\text { Photograph } \\
\text { taken after 2 } \\
\text { weeks of } \\
\text { decomposition }\end{array}$ & N/A \\
\hline $\begin{array}{l}\text { Summer } \\
2012\end{array}$ & 4 & $\begin{array}{l}\text { Day 0 (June 18, 2012) or the first day } \\
\text { of the neutron radiographs }\end{array}$ & $\begin{array}{l}\text { Days 0, 2, 3 and } \\
4\end{array}$ & Days 0, 1, 2, 3, and 4 \\
\hline $\begin{array}{l}\text { Summer } \\
2012\end{array}$ & &
\end{tabular}

Skeletal muscle samples were obtained from the quadriceps through an approximately $3 \mathrm{~cm}$ long skin incision on the anterior thigh using biopsy needles at the UTARF. Three samples of decaying skeletal muscle tissues were extracted at each sampling interval using bone biopsy needles to obtain $2 \mathrm{~mm}$ thick samples. One piece of tissue sample was removed from the biopsy needle (Figure 1A), wrapped in Al foil (Figure 1B), transported to ORNL HFIR imaging facility (Figure 1C) on ice within $1 \mathrm{hr}$, and imaged with neutrons for a few minutes (Figures 1D and 1E, gray- and color-scaled radiographs). The other two samples were fixed in formalin (24-hr fixation) for histological analysis and neutron radiography the next day, respectively. The incisions on cadavers were covered with duct tape and subsequent samplings of muscle were obtained through a new incision each time to prevent collection of damaged tissues or tissues containing insects. New incisions were made along the anterior thigh until sampling could no longer continue due to either the absence of muscle tissue, or extensive maggot activity.

\subsection{Neutron imaging facility}

The Oak Ridge National Laboratory (ORNL) Cold Guide 1D (CG-1D) neutron imaging beamline [22, 23, 26] is located at the High Flux Isotope Reactor (HFIR). The CG-1D beamline is equipped with an aperture that defines the beam geometry (i.e. pinhole geometry), a 5-meter long Helium-filled flight tube for optimum neutron transport, a combined translation/rotation sample stage for 2D and 3D imaging, and scintillation plate that converted neutrons to light signal (Figure 1C). All images were captured by a 4-Mega pixel digital charge-coupled device (CCD) that allowed quantification of neutron transmission. Samples were subjected to the neutron beam for 2-3 minutes and were exposed to approximately 1 x $10^{7}$ neutrons $/ \mathrm{cm}^{2} / \mathrm{s}$. ${ }^{6} \mathrm{LiF} / \mathrm{ZnS}$ scintillators of thickness varying from 50 to $200 \mu \mathrm{m}$ are being used at this facility to convert neutrons into light, which is subsequently detected by the CCD. Neutron imaging is based on the transmission of neutrons through an object. Neutron transmission is governed by the neutron interactions, scattering and absorption, with matter, and obeys Beer-Lambert law.

\subsection{Neutron radiography, data processing and analysis}

Samples were positioned on a translation stage between the neutron beam flight tube and the charge coupled device (CCD) camera as shown in Figure 1C. Tissues wrapped in Al were exposed to the neutron beam for 3 to 5 minutes depending on the attenuation caused by the tissue. A 2048 pixels x 2048 pixels CCD 
camera was utilized to collect neutron radiographs at a spatial resolution of $50 \mu \mathrm{m}$. Three images of the same tissue were collected each time. Under controlled conditions $\left(22{ }^{\circ} \mathrm{C}+/-2{ }^{\circ} \mathrm{C}\right.$ and $\sim 50-60 \%$ humidity), the tissues were kept wrapped in $\mathrm{Al}$ and left to decay at the neutron facility. They were measured at regular intervals over 10 days. Samples from uncontrolled conditions were measured $\sim 1 \mathrm{hr}$ after extraction at the UTARF. Transmission values were obtained from the neutron radiographs using MATLAB® [27] after image normalization. Images were normalized using Equation (1) [22, 23, 27] an in-house software iMARS [28],

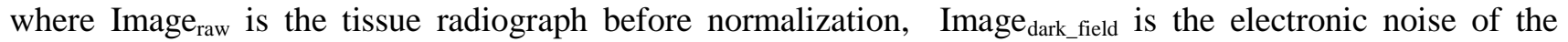

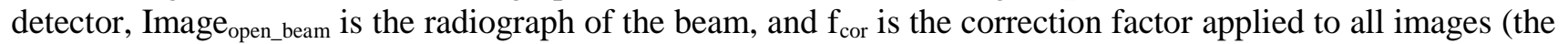
reactor flux increases at a rate of $\sim 0.5 \%$ per day). Gamma filtering was applied as a median filter using iMARS:

$$
\text { Image }_{\text {normalized }}=\frac{\text { Image }_{\text {raw }}-\text { Image dark field }_{\text {Image }}}{\text { Impen_beam-Imagedark_field }} \times f_{\text {cor. }}
$$

An example of a gray scale and color enhanced neutron radiograph of a skeletal muscle is shown in Figures $1 \mathrm{D}$ and $1 \mathrm{E}$, respectively.

During controlled conditions, five tissue replicates were measured simultaneously and three regions of interest were selected away from the edges of each sample (where the thickness may vary, thus changing the neutron transmission value). During uncontrolled conditions, one sample was used for NR studies due to the need to preserve the cadaver as much as possible and the need to extract samples for histology and formalin fixation studies too. In both conditions, three NR images were collected for each tissue specimen to provide an average transmission result.
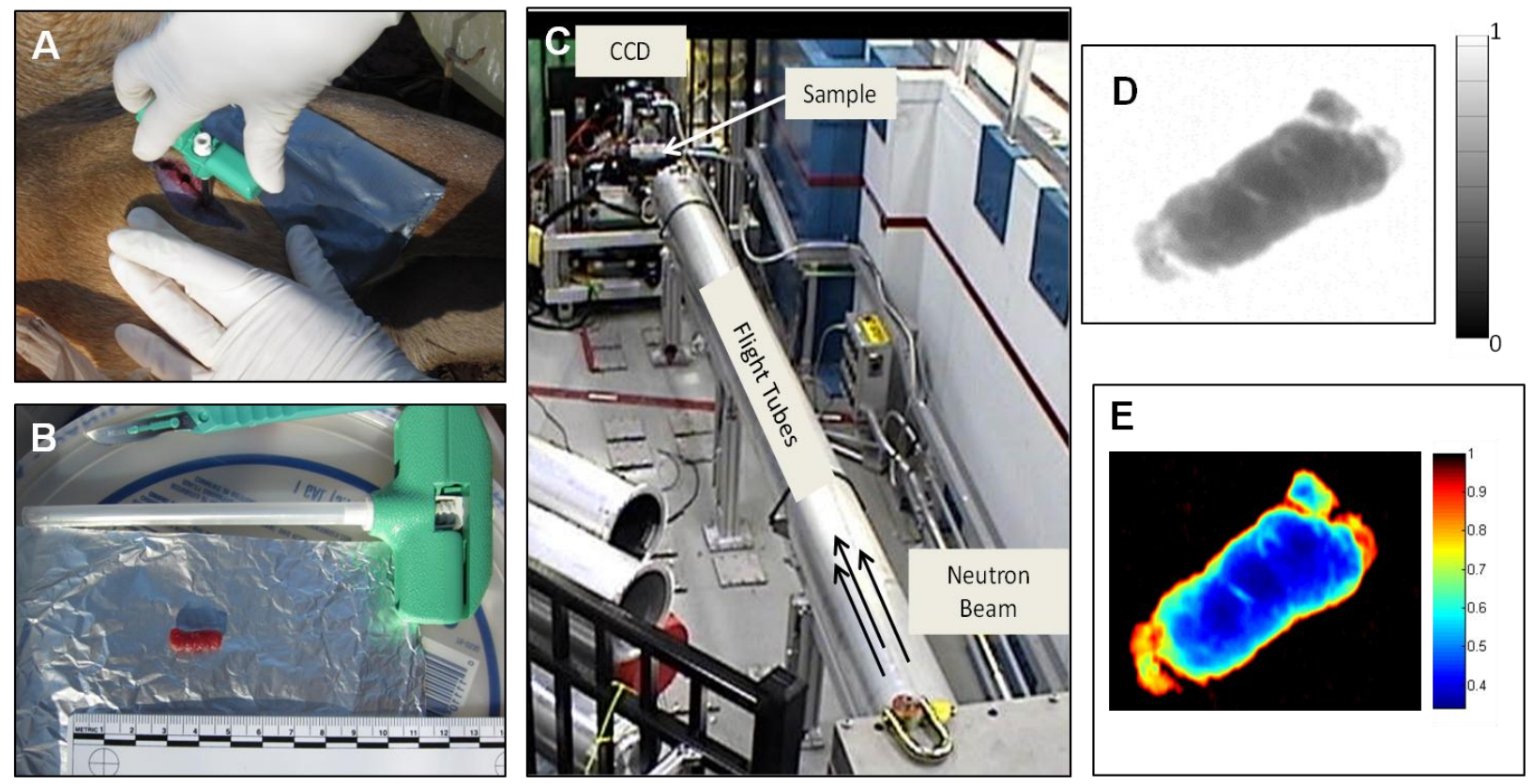

Figure 1. (A) Biopsy needle inserted in new incision, duct tape is added after each biopsy to prevent insect infestation; (B) Extracted skeletal muscle tissue and biopsy needle; (C) The HFIR neutron imaging facility; (D) Typical black and white neutron radiograph of extracted skeletal muscle, 0 and 1 on the linear scale bar indicate 0 and $100 \%$ transmission, respectively; and (E) Color enhanced neutron radiograph of the tissue in Figure 1D, 0 and 1 indicate 0 and $100 \%$ transmission.

\subsection{Histology}


Resected skeletal muscles were formalin-fixed and paraffin-embedded. Seven $\mu \mathrm{m}$ sections were used for hematoxylin and eosin (H\&E) staining to evaluate the histology of decomposed tissues. Representative images were captured using a DF73 camera attached to a Leica microscope. A 20X objective was used with a $50 \mu \mathrm{m}$ scale bar. The contrast of these images was enhanced using Adobe Photoshop version 11.0 software.

\section{Results}

3.1. External examinations of decomposed canine cadavers in uncontrolled conditions during winter and summer seasons in TN.

Photographs of the dog cadavers were acquired at the site of decomposition (UTARF) during uncontrolled environment conditions during the winter of 2011 and the summer of 2012, as illustrated in Figure 2. Day 0 corresponds to the day the cadaver was placed at the UTARF (Figure 2A), and Day 2 is a photograph taken 48 hours after placement (Figure 2B). After a month of exposure to the elements, the decomposition of the dog cadaver was not externally visible due to cold weather conditions (see Table 2) and absence of insect and scavenger activities. The average values of recorded environmental data over the duration of the study were relative low, i.e. average rain fall of $0.9 \mathrm{~mm}, 72.8 \%$ humidity, air and soil temperatures of $6.4{ }^{\circ} \mathrm{C}$ and $10{ }^{\circ} \mathrm{C}$, respectively.

During the summer experiments, and due to high average air and soil temperatures, i.e. $22.4{ }^{\circ} \mathrm{C}$ and 25.5 ${ }^{\circ} \mathrm{C}$, respectively (Table 3 ) and high insect activities, the decomposition of the cadavers that were left two and four weeks was advanced (Figures 3B and 3C) as compared to the freshly placed cadaver on Day 0 (Figure 3A). The cadaver placed six weeks prior to external examinations had reached a full skeletonized stage.

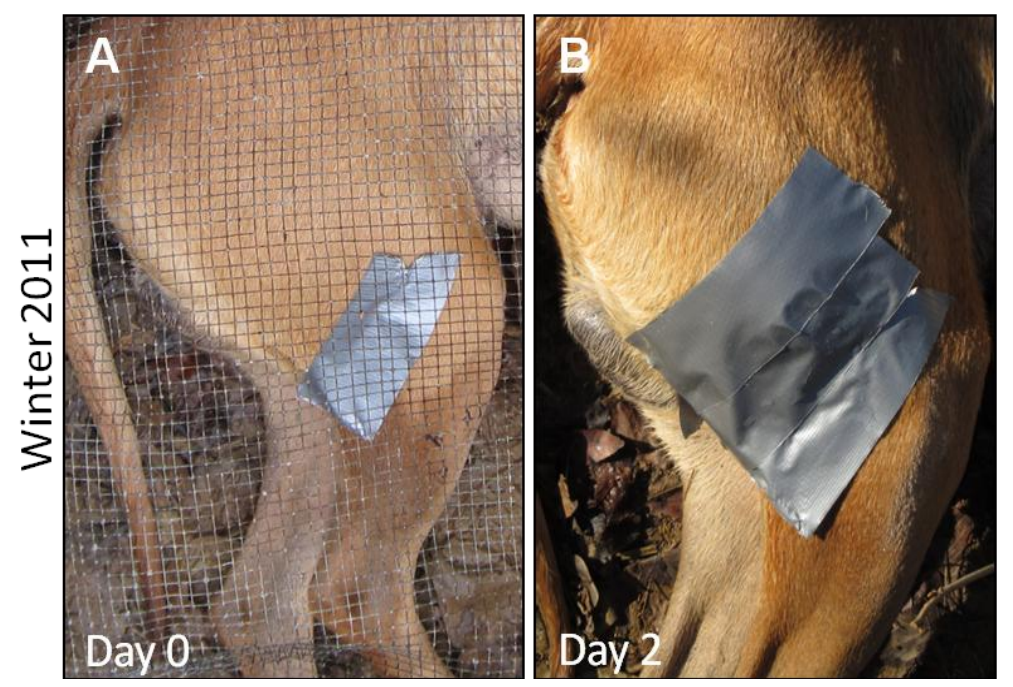

Figure 2. (A) Photograph of canine cadaver (Dog \#0, see Table 1) on the day of placement at the UTARF (Day 0); and two days after placement (B). A month after exposure to the elements, the dog outside appearance had not significantly changed from (B). 
Table 2. Recorded environmental conditions close to the burial site during winter 2011 [25]. Data comprise solar energy per surface area, rainfalls, humidity, air and soil temperatures, and high and low air temperatures.

\begin{tabular}{|c|c|c|c|c|c|c|c|}
\hline \multicolumn{8}{|c|}{ Winter 2011} \\
\hline Day & $\begin{array}{c}\text { Solar } \\
\text { (MJ/m2) }\end{array}$ & $\begin{array}{l}\text { Rain } \\
(\mathrm{mm})\end{array}$ & $\begin{array}{c}\text { Humidity } \\
(\%)\end{array}$ & $\begin{array}{c}\text { AirTemp } \\
(\stackrel{\circ}{ })\end{array}$ & $\begin{array}{c}\text { Soil Temp, } 15 \\
\text { cm depth } \\
(\underline{O C})\end{array}$ & $\begin{array}{c}\text { Air HighTemp } \\
(\underline{O C})\end{array}$ & $\begin{array}{c}\text { Air LowTemp } \\
(\underline{O})]\end{array}$ \\
\hline Day 0 & 1.25 & 5.64 & 86.20 & 5.08 & 12.60 & 9.94 & 1.62 \\
\hline Day 1 & 10.51 & 0.63 & 71.50 & 2.48 & 9.96 & 9.27 & -1.44 \\
\hline Day 2 & 10.02 & 0.31 & 74.60 & 3.71 & 9.63 & 11.06 & -2.18 \\
\hline Day 3 & 6.84 & 0.00 & 64.22 & 3.03 & 9.31 & 7.27 & 0.29 \\
\hline Day 4 & 10.82 & 0.00 & 63.86 & 2.56 & 8.27 & 10.46 & -2.31 \\
\hline Day 5 & 7.07 & 0.00 & 60.22 & 6.60 & 9.15 & 12.00 & 1.02 \\
\hline Day 6 & 3.96 & 0.00 & 75.10 & 9.50 & 10.91 & 13.79 & 7.15 \\
\hline Day 7 & 9.09 & 0.00 & 79.20 & 11.26 & N.D. & 19.57 & 6.35 \\
\hline Day 8 & 3.53 & 1.88 & 80.60 & 13.17 & N.D. & 18.52 & 6.82 \\
\hline $\begin{array}{c}\text { Average over } \\
\text { study }\end{array}$ & 7.01 & 0.94 & 72.83 & 6.38 & 9.98 & 12.43 & 1.92 \\
\hline
\end{tabular}

Table 3. Recorded environmental conditions close to the burial site during winter 2011 [25]. Data comprise solar energy per surface area, rainfalls, humidity, air and soil temperatures, and high and low air temperatures.

\begin{tabular}{|c|c|c|c|c|c|c|c|}
\hline \multicolumn{8}{|c|}{ Summer 2012} \\
\hline Day & Solar $(\mathrm{MJ} / \mathrm{m} 2)$ & Rain (mm) & Humidity $(\%)$ & AirTemp $(\mathrm{e})$ & $\begin{array}{c}\text { Soil Temp, } 15 \mathrm{~cm} \\
\text { depth (oc) }\end{array}$ & Air HighTemp (ec) & Air LowTemp (ㅇ) \\
\hline Day -41 & 15.63 & 0.31 & 70.30 & 22.58 & 25.01 & 28.21 & 19.05 \\
\hline Day -40 & 12.09 & 0.31 & 63.47 & 19.19 & 24.26 & 22.70 & 14.34 \\
\hline Day-39 & 26.57 & 0.00 & 52.62 & 16.83 & 22.78 & 23.49 & 9.88 \\
\hline Day-38 & 26.48 & 0.00 & 52.26 & 17.41 & 22.66 & 26.02 & 9.08 \\
\hline Day-37 & 12.86 & 0.00 & 65.84 & 18.34 & 22.66 & 25.69 & 13.74 \\
\hline Day-36 & 6.10 & 13.15 & 86.40 & 17.44 & 22.34 & 19.19 & 16.13 \\
\hline Day -35 & 13.18 & 21.60 & 82.00 & 18.82 & 21.65 & 25.02 & 15.53 \\
\hline Day-34 & 19.21 & 0.00 & 68.48 & 20.35 & 22.54 & 26.28 & 15.41 \\
\hline Day-33 & 21.80 & 0.00 & 67.08 & 20.14 & 22.99 & 28.15 & 13.55 \\
\hline Day-32 & 26.08 & 0.00 & 63.07 & 21.42 & 23.38 & 29.75 & 13.74 \\
\hline Day-31 & 21.30 & 0.00 & 67.25 & 21.84 & 24.25 & 29.62 & 15.81 \\
\hline Day-30 & 24.25 & 0.00 & 67.67 & 22.35 & 24.89 & 29.41 & 16.47 \\
\hline Day-29 & 25.95 & 0.00 & 63.79 & 22.71 & 25.46 & 29.48 & 16.74 \\
\hline Day-28 & 15.80 & 5.32 & 76.50 & 20.28 & 25.24 & 29.00 & 16.41 \\
\hline Day -27 & 9.04 & 6.89 & 81.30 & 19.21 & 24.24 & 24.22 & 17.20 \\
\hline Day-26 & 15.79 & 10.65 & 81.70 & 20.09 & 23.61 & 28.08 & 17.00 \\
\hline Day-25 & 24.61 & 0.00 & 68.32 & 22.37 & 24.69 & 30.80 & 16.99 \\
\hline Day-24 & 25.87 & 0.00 & 65.92 & 24.08 & 25.60 & 32.79 & 16.41 \\
\hline Day-23 & 24.62 & 0.00 & 67.04 & 25.34 & 26.62 & 33.26 & 18.79 \\
\hline Day-22 & 24.61 & 0.00 & 66.16 & 26.02 & 27.37 & 33.59 & 19.86 \\
\hline Day-21 & 25.49 & 0.00 & 61.29 & 26.63 & 27.84 & 34.27 & 19.86 \\
\hline Day-20 & 19.57 & 0.00 & 69.12 & 24.66 & 27.97 & 32.19 & 20.12 \\
\hline Day-19 & 27.19 & 0.00 & 59.16 & 25.34 & 27.85 & 33.20 & 19.26 \\
\hline Day-18 & 21.57 & 8.45 & 64.96 & 23.22 & 27.78 & 31.59 & 17.27 \\
\hline Day-17 & 14.59 & 13.15 & 75.50 & 19.41 & 26.26 & 22.83 & 15.20 \\
\hline Day-16 & 25.45 & 0.00 & 59.39 & 17.11 & 24.60 & 23.55 & 10.74 \\
\hline Day-15 & 23.29 & 0.00 & 62.66 & 20.88 & 24.82 & 29.21 & 12.82 \\
\hline Day-14 & 15.52 & 0.00 & 64.68 & 22.70 & 25.62 & 29.75 & 18.79 \\
\hline Day-13 & 23.40 & 5.64 & 61.70 & 21.05 & 25.39 & 26.81 & 16.13 \\
\hline Day-12 & 22.61 & 0.00 & 54.33 & 20.95 & 25.00 & 27.62 & 14.27 \\
\hline Day-11 & 23.74 & 0.00 & 55.20 & 21.74 & 25.32 & 29.08 & 14.87 \\
\hline Day-10 & 27.96 & 0.00 & 51.00 & 22.23 & 25.57 & 29.48 & 15.41 \\
\hline Day-9 & 22.51 & 0.00 & 60.82 & 23.43 & 25.59 & 30.46 & 16.47 \\
\hline Day-8 & 13.22 & 0.31 & 71.30 & 22.77 & 26.29 & 27.81 & 20.05 \\
\hline Day-7 & 13.31 & 3.44 & 78.10 & 22.85 & 25.27 & 28.28 & 19.72 \\
\hline Day-6 & 16.73 & 2.51 & 75.60 & 24.32 & 25.65 & 29.15 & 20.72 \\
\hline Day-5 & 23.62 & 0.00 & 60.39 & 24.64 & 26.03 & 31.27 & 17.99 \\
\hline Day -4 & 22.10 & 0.00 & 61.67 & 24.23 & 26.22 & 33.33 & 18.33 \\
\hline Day-3 & 23.35 & 0.00 & 64.04 & 24.89 & 26.72 & 32.33 & 18.86 \\
\hline Day-2 & 18.36 & 3.13 & 67.83 & 24.11 & 27.18 & 29.22 & 20.12 \\
\hline Day-1 & 21.33 & 0.00 & 64.48 & 24.37 & 26.43 & 30.73 & 19.72 \\
\hline Dayo & 27.10 & 0.00 & 58.19 & 25.83 & 27.15 & 32.66 & 18.73 \\
\hline Day 1 & 25.52 & 0.00 & 58.76 & 26.01 & 27.59 & 34.25 & 18.66 \\
\hline Day 2 & 24.87 & 0.00 & 57.00 & 27.35 & 28.57 & 34.19 & 20.65 \\
\hline Day 3 & 23.77 & 2.82 & 61.09 & 27.39 & 29.37 & 34.92 & 21.12 \\
\hline Day 4 & 23.83 & 0.31 & 62.79 & 27.23 & 29.46 & 35.32 & 21.65 \\
\hline Average over study & 20.91 & 2.13 & 65.61 & 22.44 & 25.52 & 29.31 & 16.95 \\
\hline
\end{tabular}



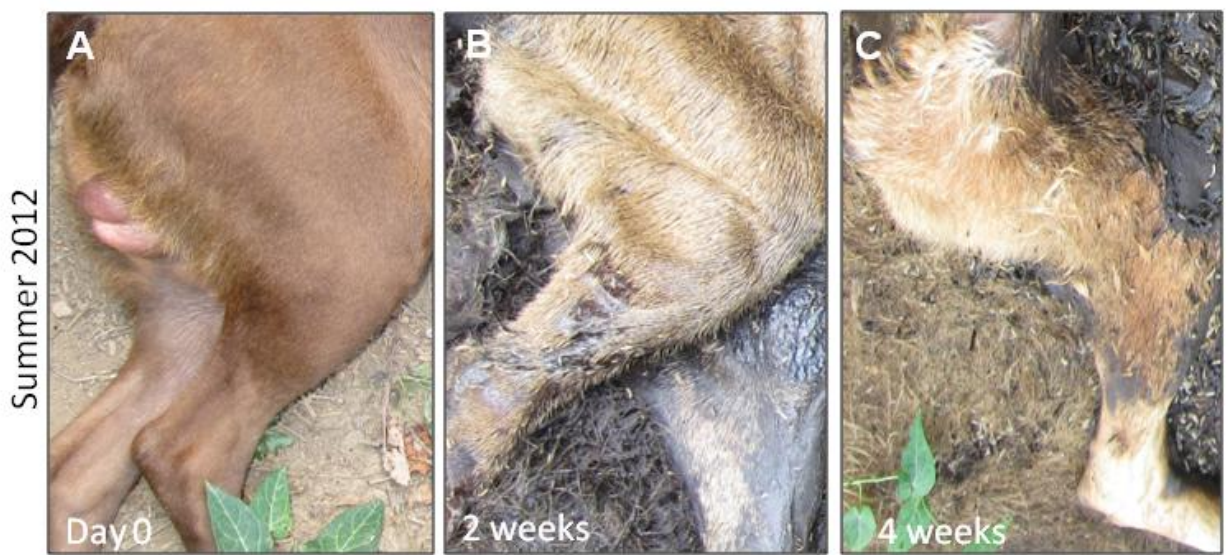

Figure 3. State of decomposition of canine cadavers placed (A) the same day (Dog \#4, see Table 1), (B) 2 weeks (Dog \#3, see Table 1) and (C) 4 weeks (Dog \#2, see Table 1) prior to the day photographs were taken.

\subsection{Neutron radiography of canine skeletal muscle under controlled conditions}

The transmission of neutrons through skeletal muscle tissue (Figure 4A) was normalized (Figure 4B), color coded (Figure 4C) and transmission data were plotted as function of time as shown in Figure 4D. Similar pattern of the increased transmission was observed in fresh lung and bone as shown in Figures 5A-D and 6A$\mathrm{D}$, respectively. Over a period of 10 days, changes in neutron transmission through lung and muscle were higher than bone. The transmission of lung, muscle and bone tissue increased by $8.3 \%, 7.0 \%$ and $2.0 \%$, respectively, over 10 days. The largest change in transmission in lung and muscle may be attributed to their decay rate, thus they may outgas $\mathrm{H}$ a lot quicker than bones. The main contributor of $\mathrm{H}$ in bones is the bone marrow and blood. It is likely that its decay is slower due to minimal loss of $\mathrm{H}$ content.

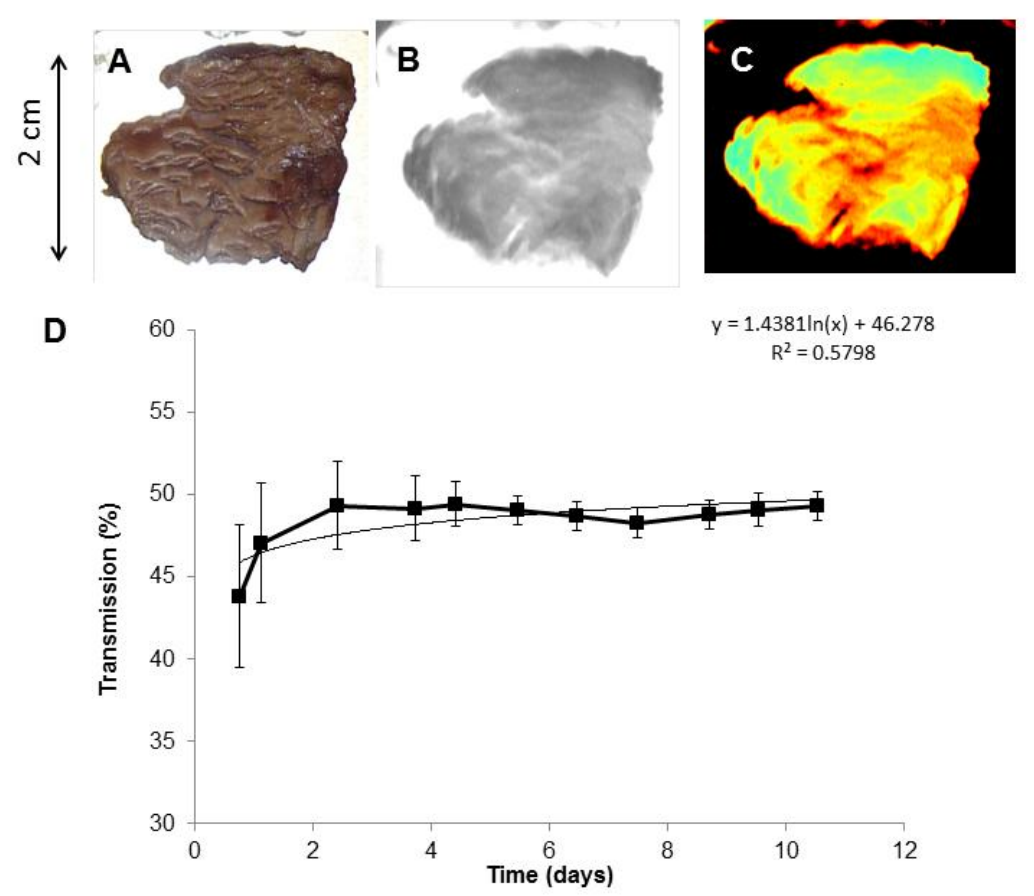

Figure 4. (A) Photograph, (B) gray scale and color enhanced (C) neutron radiograph of a $2 \mathrm{~cm} \mathrm{x} 2 \mathrm{~cm} \mathrm{x} 1 \mathrm{~mm}$ thick skeletal muscle tissue. (D) Neutron transmission as a function of time of skeletal muscle tissues under controlled conditions with natural logarithm fit. (Gray and color scales are the same as in Fig. 1.) 

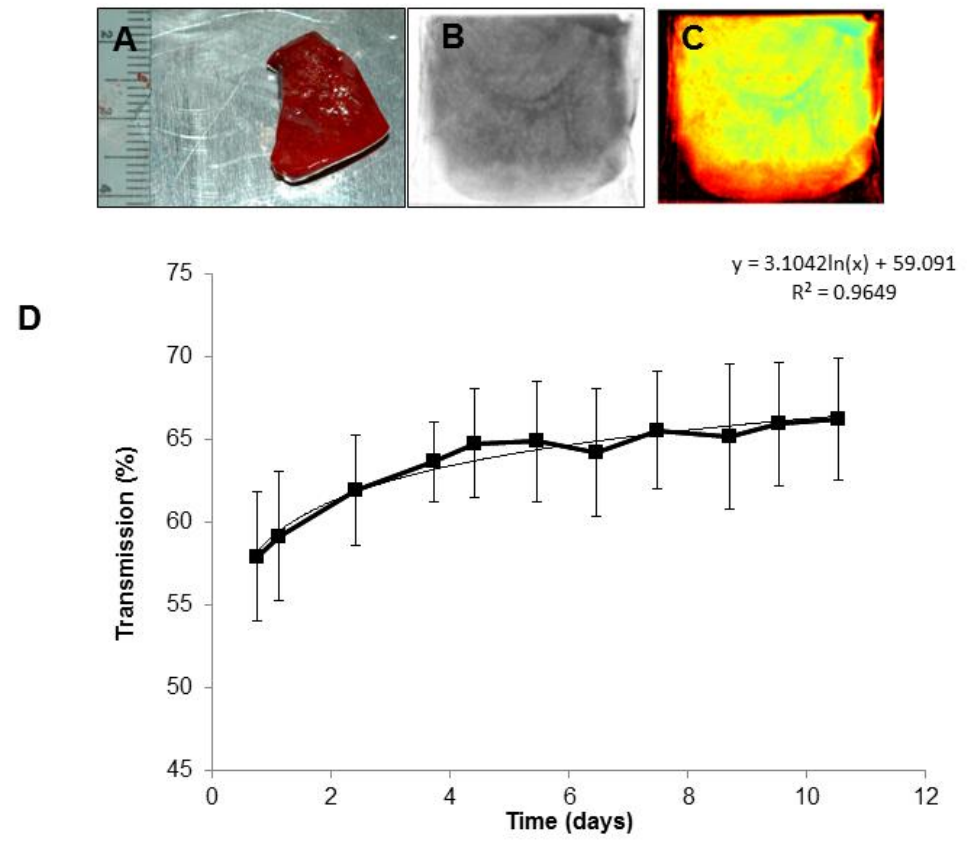

Figure 5. (A) Representative photograph, (B) gray scale and color enhanced (C) neutron radiograph of a $2 \mathrm{~cm} \times 2 \mathrm{~cm} \times 1$ $\mathrm{mm}$ thick lung tissue. (D) Neutron transmission as a function of time of lung tissues under controlled conditions with natural logarithm fit. (Gray and color scales are the same as in Fig. 1.)
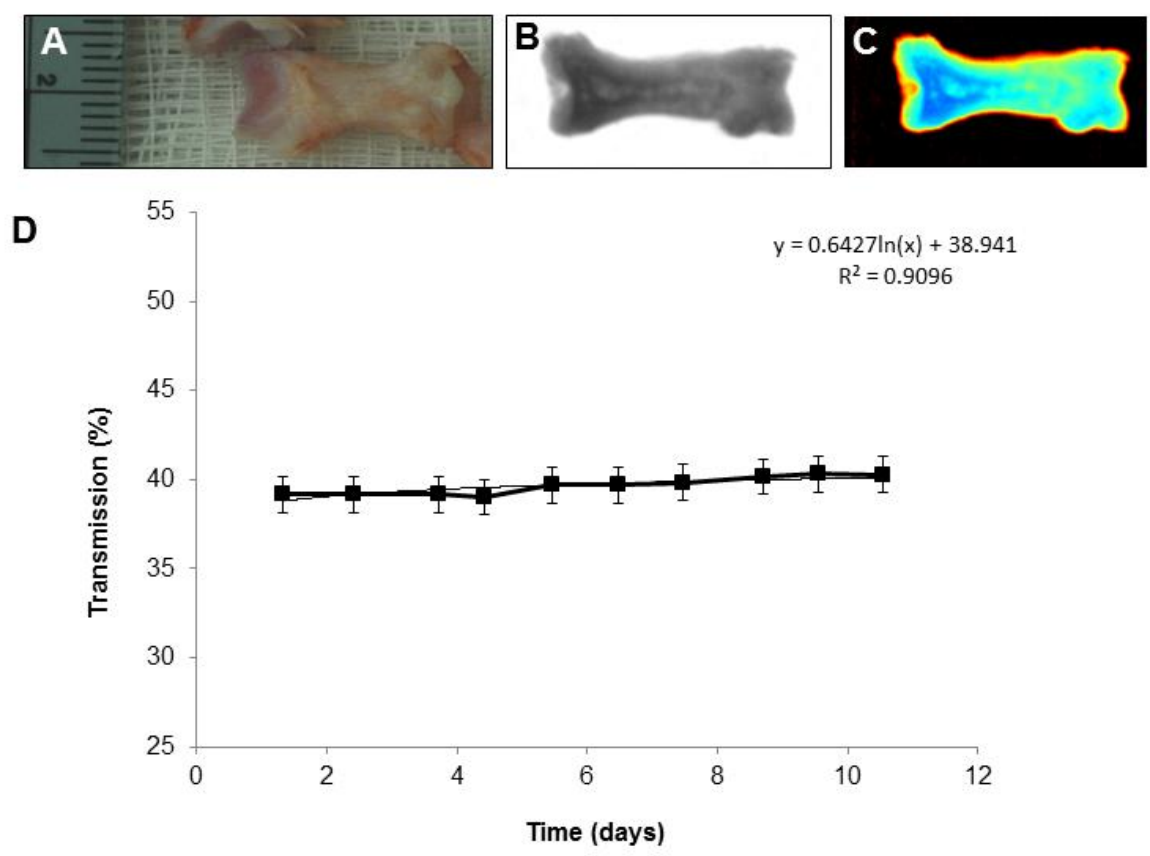

Figure 6. (A) Photograph, (B) gray scale and color enhanced (C) neutron radiograph of a $2 \mathrm{~cm} \mathrm{x} 2 \mathrm{~cm} \times 1 \mathrm{~mm}$ thick bone. (D) Neutron transmission as a function of time of bones under controlled conditions with natural logarithm fit. (Gray and color scales are the same as in Fig. 1.)

\subsection{Estimate of the PMI for tissues decayed under controlled conditions}

Both linear regression and natural logarithmic fit methods were used to assess the relationship between transmission and time of decay for each type of tissue (lung, bone and muscle, respectively). The natural logarithmic fit was found to give the highest fit accuracy value, $\mathrm{R}^{2}$, and was thus chosen for the PMI 
estimate. The first neutron radiograph measured at CG-1D corresponds to $t=0.75$ day after time of death. This estimate is based on the accumulated time tissues were left at room temperature prior to neutron imaging measurements and does not include the amount of time tissues spent in the necropsy refrigerator at UTK CVM. Changes in neutron transmission is not detectable when the tissues were stored for a few hours in the refrigerator. The change in transmission, $\langle\Delta$ Transmission $>$, over 24 hours was calculated from the averaged transmission change over 10 days and its value was used to calculate the expected transmission at time of death. The predicted neutron transmission of bones at the time of death, $T_{\text {time of death }}$, was estimated by subtracting the product of $\langle\Delta$ Transmission $>$ and the number of hours the canine cadaver was left to decay, $t_{\text {decay }}$, from the first measured neutron transmission, $T_{t=0.75}$, at $t=0.75$ day

$$
T_{\text {time of death }}=T_{t=0.75}-\left(<\Delta \text { Transmission }>x t_{\text {decay }}\right) .
$$

The estimated PMI was calculated using the natural logarithmic fit and, using the estimated transmission $\mathrm{T}_{\text {time of death }}$, as enunciated in Eq. 2. Table 4 provides the estimated PMI for each tissue, with its respective accuracy. The fit accuracy $\left(\mathrm{R}^{2}\right)$, the average transmission change over 24 hours $\langle\Delta$ Transmission $\rangle$, its standard deviation STD and standard error SE are also provided.

Table 4. Estimated PMI for each tissue, with its respective accuracy, $\mathrm{R}^{2}$. The fit accuracy $\left(\mathrm{R}^{2}\right)$, the average transmission change over 24 hours $\langle\Delta$ Transmission $>$, its standard deviation STD and standard error SE are also provided. The true PMI was $18 \mathrm{~h}$. The accuracy of the PMI is calculated as the ratio of the estimated-to-true PMI value.

\begin{tabular}{|c|c|c|c|c|c|c|c|}
\hline Tissue Type & $\mathbf{R}^{2}$ & Atransmission & STD & SE & Estimated PMI (h) & PMI (h) & Accuracy (\%) \\
\hline Bones & 0.91 & 0.002 & 0.002 & 0.0006 & 12.6 & 18 & 70.0 \\
\hline Muscles & 0.58 & 0.008 & 0.011 & 0.0034 & 0.25 & 18 & 1.4 \\
\hline Lungs & 0.94 & 1.036 & 0.790 & 0.2495 & 11.5 & 18 & 63.9 \\
\hline
\end{tabular}

\subsection{Neutron radiography of canine skeletal muscle under uncontrolled during winter and summer seasons}

Winter 2011 was mild with a few overnight freezes. Summer 2012 was hot and humid. These two different seasons were selected by the team to compare the two most opposite environmental conditions in TN.

Skeletal muscle samples were collected from canine cadavers placed at the UTARF during the winter of 2011. The 2-mm biopsied samples were imaged over a period of 9 days. Changes in transmission over time were $5.7 \%$ and $6.3 \%$ for the fresh and fixed tissues, respectively, but there was no continuous increase of the transmission, as observed during controlled conditions (see Figure 4D). Although no insect activities were clearly apparent during the winter season, changes in humidity are significant enough to change the $\mathrm{H}$ composition in the resected tissues. Moreover, due to limited access to the imaging beamline, the team was not able to measure transmission of the tissues on a daily basis. The number of tissues was limited for reasons mentioned in $\S 2.3$, thus error bars were not calculated in Figure 7. 


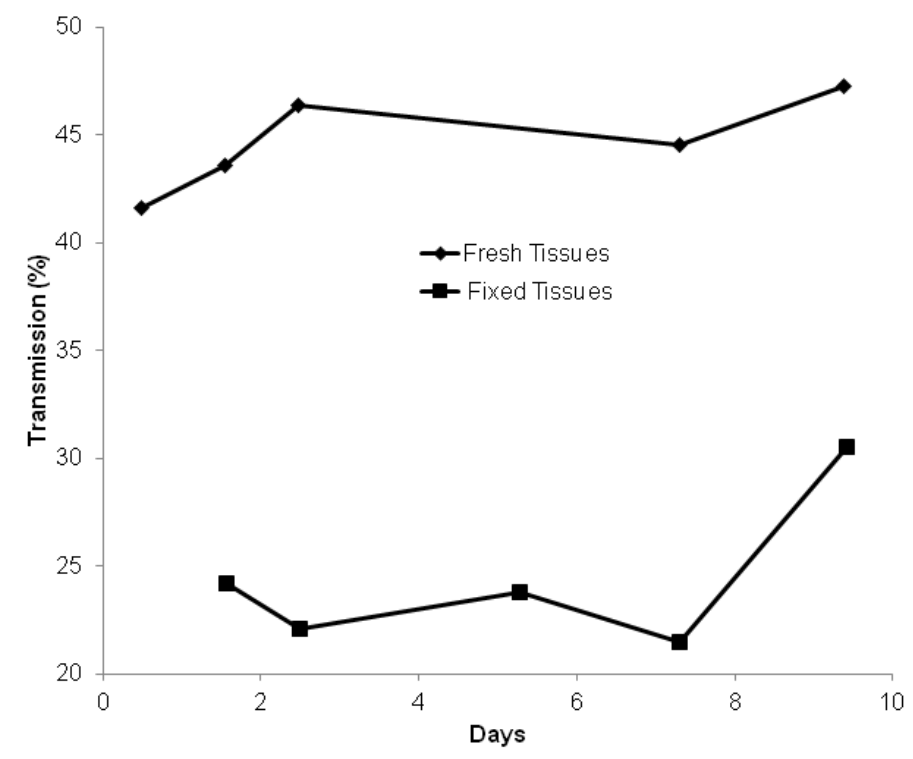

Figure 7. 2-mm thick skeletal muscle neutron transmission as a function of time during winter 2011.

During the summer of 2012, the canine cadaver placed at the UTARF the first day of the neutron imaging experiments was used to obtained muscle biopsies to evaluate changes in skeletal muscle by neutron radiography and histology analysis after 24-hr fixation with formalin over a period of 5 days. Rapid decay caused predominantly by insect activity did not allow collection of skeletal muscle tissues after 4 days as shown in Figures 3 and 8A. Neutron transmission was evaluated as illustrated in Figure 9. Similarly to the winter of 2011, one sample was fixed using formalin to stop further decay and neutron transmission was measured the next day at the beamline. Fixation of the sample tissue after removal may facilitate the transport of samples to a diagnostic facility. Our preliminary research (not shown here) had demonstrated that fixation of a tissue creates an offset in the neutron data that can be corrected during data processing. In the summer, changes in neutron transmission over time varied significantly in a 5-day period. The transmission of the fresh skeletal muscles decreased over time by $6.3 \%$ instead of the expected increase, which was likely due to the exposure of the carcass to rainfall and humidity (Table 3). The transmission of fixed tissues increased by $7.2 \%$ over 5 days, with a peak that corresponded to an increase in humidity (without rainfall, see Table 3), which is counter-intuitive and might be indicative of the sample outgassing $\mathrm{H}$ faster than it is collecting $\mathrm{H}$ from moisture in the air.

\subsection{Histology analysis of canine skeletal muscle under uncontrolled during summer 2012}

After formalin fixation and paraffin embedding of obtained samples (Figure 8A), the histology of the decaying skeletal muscle was evaluated (Figure $8 \mathrm{~B}$ ). The representative images of the skeletal muscle histology during the decay process over 5-days period are shown in Figure 8B. On Day 0, a few hours after death, the image showed the typical light microscopic features of skeletal muscle. The muscle fibers were longitudinally aligned with predominantly peripheral, oval to oblong (cigar-shaped) euchromatic nuclei and well defined cytoplasmic cross striations. Intermuscular stromal collagen, fibrocytes, vessels and nerves were typical and well defined. The activity of the inter-muscular bacterial bacilli were multifocally present already on Day 1, (purple sticks) between the muscle fibers that maintained cross striation with rare homogenization, and increased on Day 2 and Day 3 as shown in Figure 8B. Peripheral nuclei (purple color) of the skeletal muscle cells were condensed and elongated to absent on Day 0 and Day 1 . The disappearance of the nuclei and the destroyed structures of the muscle fibers have been detected since Day 2 with decreased eosin stainuptake by basic cytoplasm confirming the degradation of the present proteins in cells. Eosinophilia of the myofibers was decreased and cross striations were exaggerated by fiber separation between. Intermuscular bacteria were present and there was dystrophic mineralization of adipocytes. On Day 3, no nuclei were discernible. There was continued diminished eosinophilia of myofibers. Cross striation was not discernible in the majority of the muscle fibers. There was occasional peripheral fibrillation to fragmentation of the fibers. 
Intermuscular bacteria were present and there was dystrophic mineralization of adipocytes. After Day 4, there is no detectible organization structure of the muscle fibers with increased fibrillation and fragmentation of fibers.
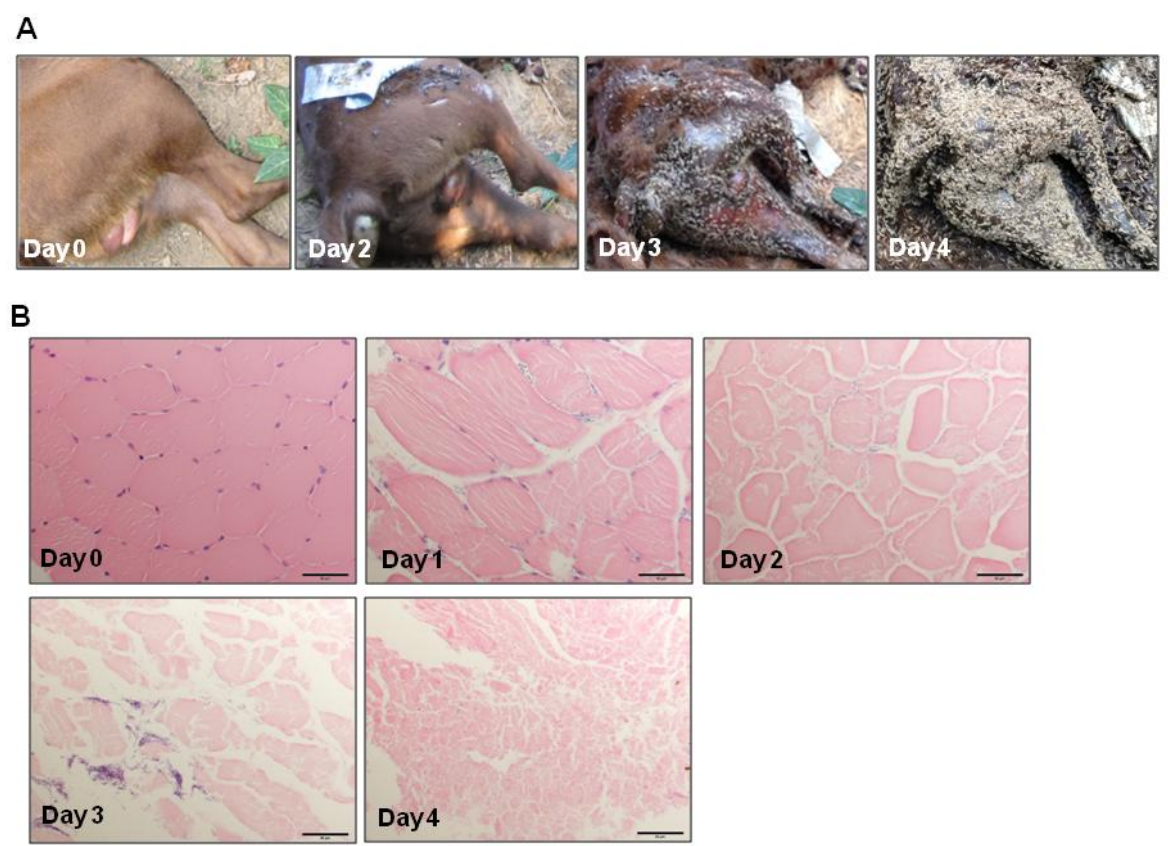

Figure 8. (A) Photograph of canine cadavers over time during summer 2012, and (B) histology images of skeletal muscle tissues during the 5-day decay period.

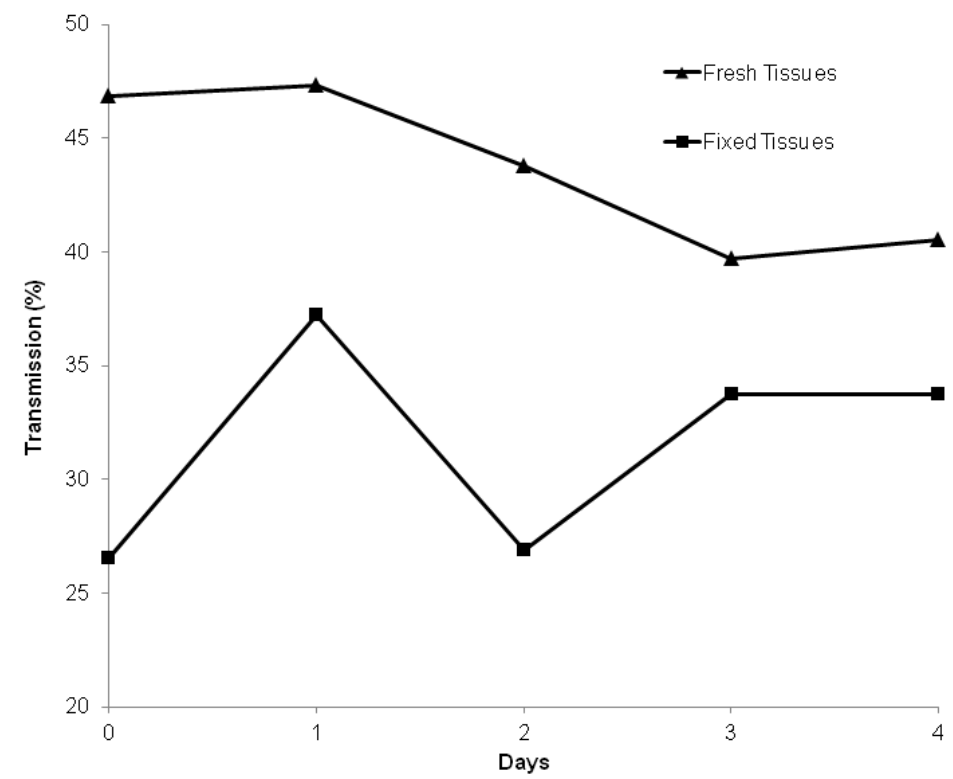

Figure 9. 2-mm thick skeletal muscle neutron transmission as a function of time during summer 2012. 


\section{Discussion}

This proof-of-concept research focuses on attempting to establish a relationship between PMI and neutron transmission. One of the most difficult challenges in forensic research for criminal justice investigations is to determine objectively post-mortem interval (PMI). The accuracy of PMI is a critical piece of information for the determination of a timeline of events surrounding death. Most PMI techniques rely on gross observational changes of cadavers that are subjective to forensic anthropologists [29, 30]. The decomposition of the cadavers is also highly sensitive to environmental conditions [29]. Recent studies have demonstrated that even exhumed individuals with same environmental conditions and same PMI show different stages of decomposition [30].

Decay studies of canine skeletal muscles, bone, and lung tissues were conducted under controlled environmental conditions. These tissues were chosen to cover a different time frame of PMI. Under these conditions, a natural logarithmic increase in transmission was measured in lung, skeletal muscle and bone tissues. Our data indicate that for the determination of early PMI (days after death), lung tissues could be utilized as the changes in measured neutron transmission are the highest, i.e. an overall change of $8.3 \%$ over 10 days, while bones, with a neutron transmission increase of $2 \%$, could be used as later-range PMI estimate tissue candidates (weeks to months after death).

Under controlled conditions, estimation of the PMI was 12.6 hours and 11.5 hours with neutron radiography of bones and lungs, respectively, while it was $0.25 \mathrm{hr}$ with the muscle tissue. All results underestimated the true PMI of $18 \mathrm{hr}$. The discrepancy in skeletal muscle PMI estimate accuracy may be due to the fat content and alignment of the muscle fibers that can affect neutron transmission. Fat content can vary in a cadaver and may putrefy at a different rate than soft tissue [31]. We measured changes in neutron transmission of muscles, i.e. areas that appear completely transparent to neutrons indicating a likely separation of muscle fibers (see Figs. 4B and C) for which photographs did not indicate any fiber separation (Fig. 4A). This discrepancy in the PMI estimate is also reflected by the inability to fit the data with a natural logarithmic function with the same $\mathrm{R}^{2}$ accuracy as shown for bones and lungs (Table 4).

The choice of tissue (lung, muscle, or bone) directly affects the neutron transmission or $\mathrm{H}$ content changes in the decaying tissue though time. It is likely due to the different decay rate in the tissue. Depending on environmental conditions, skeletal muscle will decay in a few days, but this can extend to a few weeks, as observed at the UTARF during winter 2011. Finally, bones outlast all "soft" tissues. These different putrefaction rates may be an advantage for this technique. Depending on the stage of decomposition of the human remains at the death scene, PMI can be estimated using short-lasting samples such as lungs and/or muscles, or long-lasting samples such as bones when the decomposition is advanced.

While controlled conditions data provide a natural logarithmic response in neutron transmission, the uncontrolled measurements did not yield any obvious relationship between transmission and time elapsed since death. The data is highly affected by environmental conditions and further studies that isolate each environmental component (humidity, rain fall, heat, etc.) should be conducted thoroughly. The choice of summer measurements at the UTARF seems a less optimal time to collect muscle tissue samples due to excessive insect activity. The summer study was limited to 5 days, approximately half the amount of time of the winter and controlled-condition measurements. Uncontrolled winter conditions did not yield any results that can be fitted either, reinforcing that cadavers left to the elements (variation in humidity, see Table 2) can change and although the neutron technique is capable of detecting $\mathrm{H}$ changes through time, there is no possibility to estimate PMI due to variation in moisture uptake by the cadavers.

Fixation of the tissue offers the option to "freeze" the sample in time, and transport it to a location where neutron imaging can be performed. The effect of chemicals used for humane euthanasia of dogs on neutron radiography was not evaluated in this study.

\section{Conclusion}

In conclusion, this study shows that neutrons are capable of detecting changes in resected tissue samples such as skeletal muscles, lung and bones. Although the results did not provide any insight into the relationship between change in transmission and PMI under uncontrolled conditions, the measurements were successful at determining PMI in the case of controlled conditions with both decaying bone and lung tissues, with 70 and $64 \%$ accuracy, respectively. 
Further research should focus on using human remains rather than canine cadavers to remove the possible effect of chemicals used for humane euthanasia. The use of human cadavers will be more representative of the death scene remains. The next step of this research should focus on establishing statistical models from neutron imaging data of human cadavers under different environmental conditions. Several environmental factors can play an "intertwined" role in the decomposition of a cadaver, making the PMI estimate using neutron radiography of resected tissue complex. This research will require the establishment of a database or library that contains neutron transmission data of selected tissues for a specific body type, climate, state of decomposition, insect activity, etc. These factors will be essential in developing modeling PMI estimate from neutron transmission measurements.

With the advances of portable neutron generators development, the devices have become more affordable and with appropriate algorithms based from neutron data and modeling, it is conceivable that a system could be installed in a law enforcement vehicle and used at the crime scene to estimate H content and thus PMI.

\section{REFERENCES:}

[1] A. A. Vass, R. I. Fleming, S. Harbinson, J. M. Curran,. and E. Williams, "Nucleic Acid Degradation and the Postmortem Interval", Proceedings: American Academy of Forensic Sciences, Atlanta, GA, Feb 20-25, 2012, (G36, p.295-6).

[2] A. A. Vass, "Dust to Dust - how a human body decomposes", Scientific American - Special Issue "The End.”, pp 56-59, September, 2010.

[3] A. A. Vass, "Beyond the Grave - Understanding Human Decomposition", Microbiology Today, 28:190192, Nov, 2001.

[4] A. A. Vass, "The Elusive Universal Post-Mortem Interval Formula", Forensic Science Int. 204 (2011) 3440 .

[5] A. A. Vass, A.A., W. M. Bass, J. D. Wolt, J.D., J. E. Foss, J. T. Ammons, "Time Since Death Determinations of Human Cadavers Using Soil Solution", Journal of Forensic Sciences, 37(5):1236-1253, Sept. 1992.

[6] A. A. Vass, S.-A. Barshick, G. Sega, J. Caton, J. T. Skeen, J. C. Love, J.C., J. A. Synstelien, "Decomposition Chemistry of Human Remains: A New Methodology for Determining the Postmortem Interval”, Journal of Forensic Sciences 47(3):542-553, 2002.

[7] M. K. Mark., J. C. Love and I. R. Dadour. 2009, "Taphonomy and Time: Estimating the postmortem interval", In: Steadman, D.W. (ed)., Hard Evidence: Case Studies in Forensic Anthropology, 2nd ed. Upper Saddle River, NJ: Prentice Hall. pp 165-178.

[8] H. Gill-King, "Chemical and Ultrastructural Aspects of Decomposition", In: Haglund WD, Sorg MH., editors. Forensic Taphonomy: The Postmortem Fate of Human Remains. Florida. Boca Raton: CRC Press, 1997;93-104.

[9] R. Singh Ahi and V. Garg, "Role of vitreous potassium level in estimating post-mortem interval ad the factors affecting it", Journal of Clinical and Diagnostic Research, Vol. 5(1), 2011, 13-15.

[10] M.A. Clark, M. B. Worrell, J.E. Pless, "Postmortem Changes in Soft Tissues", In: Haglund WD, Sorg MH., editors. Forensic Taphonomy: The Postmortem Fate of Human Remains. Florida. Boca Raton: CRC Press, 1997;151-160.

[11] A. A. Vass, " Odor Mortis", Forensic Science Int. 222 (2012) 234-241. 
[12] A. A.Vass, R. R. Smith, C. V. Thompson, M. N. Burnett, N. Dulgerian, B. A. Eckenrode, "Odor Analysis of Decomposing Buried Human Remains", J. Forensic Sciences, 53 (2): 384-392, March 2008.

[13] A. A. Vass, R. R. Smith, C. V. Thompson, M. N. Burnett, D. A. Wolf, J. A. Synstelien, B. A. Eckenrode, N. Dulgerian, "Decompositional Odor Analysis Database", J. Forensic Sciences, 49 (4): 760-769, July 2004.

[14] P. Rulshrestha, H. Chandra, "Time Since Death: An Entomological Study on Corpses", Am.

J. Forensic Med. Pathol 1987;8:233-245.

[15] B. Keh, "Scope and Applications of Forensic Entomology", Annual Review of Entomology 1985;30:137-154.

[16] W. C. Rodriquez, W. M. Bass, "Insect Activity and Its Relationship to Decay Rates of Human Cadavers in East Tennessee", Journal of Forensic Science 1983;28:423-432.

[17] N.H. Haskell, R. D. Hall, V. J. Cervenka, M. A. Clark, "On the Body: Insects' Life Stage

Presence, Their Postmortem Artifacts", In: Haglund WD, Sorg MH, editors. Forensic

Taphonomy: The Postmortem Fate of Human Remains. Florida. Boca Raton: CRC Press, $1997 ; 415-441$.

[18] Neutron Imaging and Applications: A Reference for the Imaging Community, Series: Neutron Scattering Applications and Techniques, Eds. I. S. Anderson, R. McGreevy, H. Z. Bilheux, DOI 10.1007/978-0-38778693-3_14, Springer Science+Business Media, LLC 2009.

[19] M. Strobl, I. Manke, N. Kardjilov, A. Hilger, M. Dawson and J. Banhart, "Advances in Neutron Radiography and Tomography", J. Phys. D.: Appl. Phys. 42 (2009) 243001 (21pp).

[20] E. Lehmann, A. Kaestner, L. Josic, S. Hartmann, D. Mannes, "Imaging with cold neutrons", Nuclear Instruments and Methods in Physics Research A, 605 (2009) 13-15.

[21] N. Kardjilov, A. Hilger, I. Manke, M. Strobl, M. Dawson, J. Banhart, "New trends in neutron imaging", Nuclear Instruments and Methods in Physics Research A, 651 (2011) 161-165.

[22] M. Cekanova, R. Donnell, H. Bilheux, J. Bilheux, "Neutron imaging: Detection of cancer using animal model", Biomedical Science and Engineering Center Conference (BSEC), 2014 Annual Oak Ridge National Laboratory, vol., no., pp.1,4, 6-8 May 2014, doi: 10.1109/BSEC.2014.6867752.

[23] H. Z. Bilheux, J.-C. Bilheux, W. B. Bailey, W. S. Keener, L. E. Davis, K. W. Herwig, M.Cekanova, "Neutron imaging at the Oak Ridge National Laboratory: Application to biological research", Biomedical Science and Engineering Center Conference (BSEC), 2014 Annual Oak Ridge National Laboratory, vol., no., pp.1,4, 6-8 May 2014; doi: 10.1109/BSEC.2014.6867751.

[24] K. L Stokes, S. L. Forbes, M. Tibbett, "Human Versus Animal: Contrasting Decomposition Dynamics of Mammalian Analogues in Experimental Taphonomy", Journal of Forensic Sciences 58 *2013) 583-591.

[25] http://bioengr.ag.utk.edu/weather/

[26] L. Crow, L. Robertson, H. Bilheux, M. Fleenor, E. Iverson, X. Tong, D. Stoica, W. T. Lee, "The CG1 instrument development test station at the high flux isotope reactor" Nuclear Instruments and Methods in Physics Research A, 634 (2011) S71-S74.

[27] MATLAB ${ }^{\circledR}$ is a commercial software developed by The MathWorks Inc., Natick, MA, 2000. 
[28] iMARS is an in-house GUI compiled as an executable and available to support the neutron scattering user community that utilizes the CG-1D imaging beamline. The programming language is MATLAB®.

[29] M. T. Ferreira and E. Cunha, "Can we infer post-mortem interval on the basis of decomposition rate? A case from a Portuguese cemetery", Forensic Science International, 226 (2013) 298.e1-298.e6.

[30] N. Hoke, A. Grigat, G. Grupe, M. Harbeck, "Reconsideration of bone post-mortem interval estimation by UV-induced autofluorescense", Science International, 228 (2013) 176.e1-176.e6.

[31] R. C. Janaway, S. L. Percival, A. S. Wilson, "Decomposition of human remains", Microbiology and Aging, Chapter 14 (2009), pp. 313-334, Publisher: Humana Press, DOI: 10.1007/978-1-59745-327-1_14 

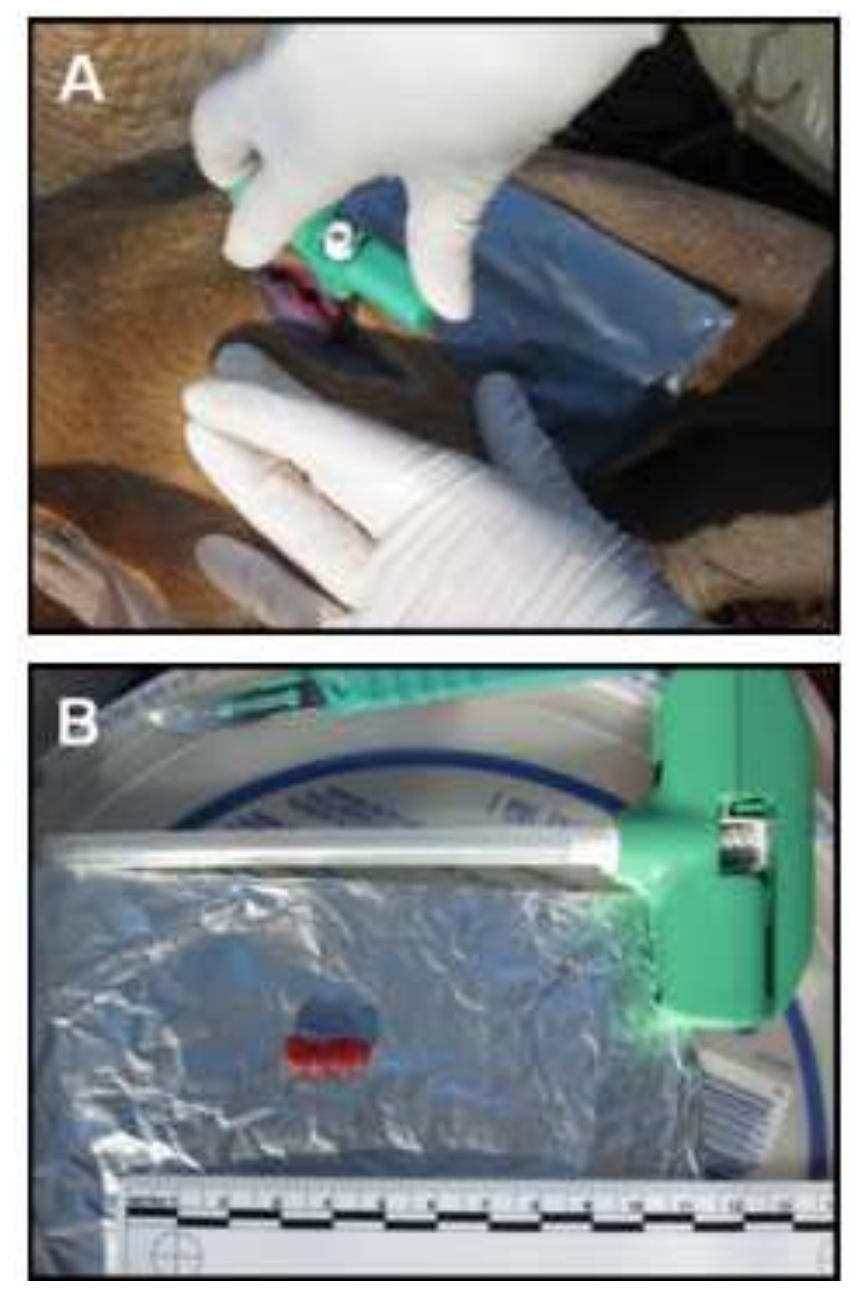
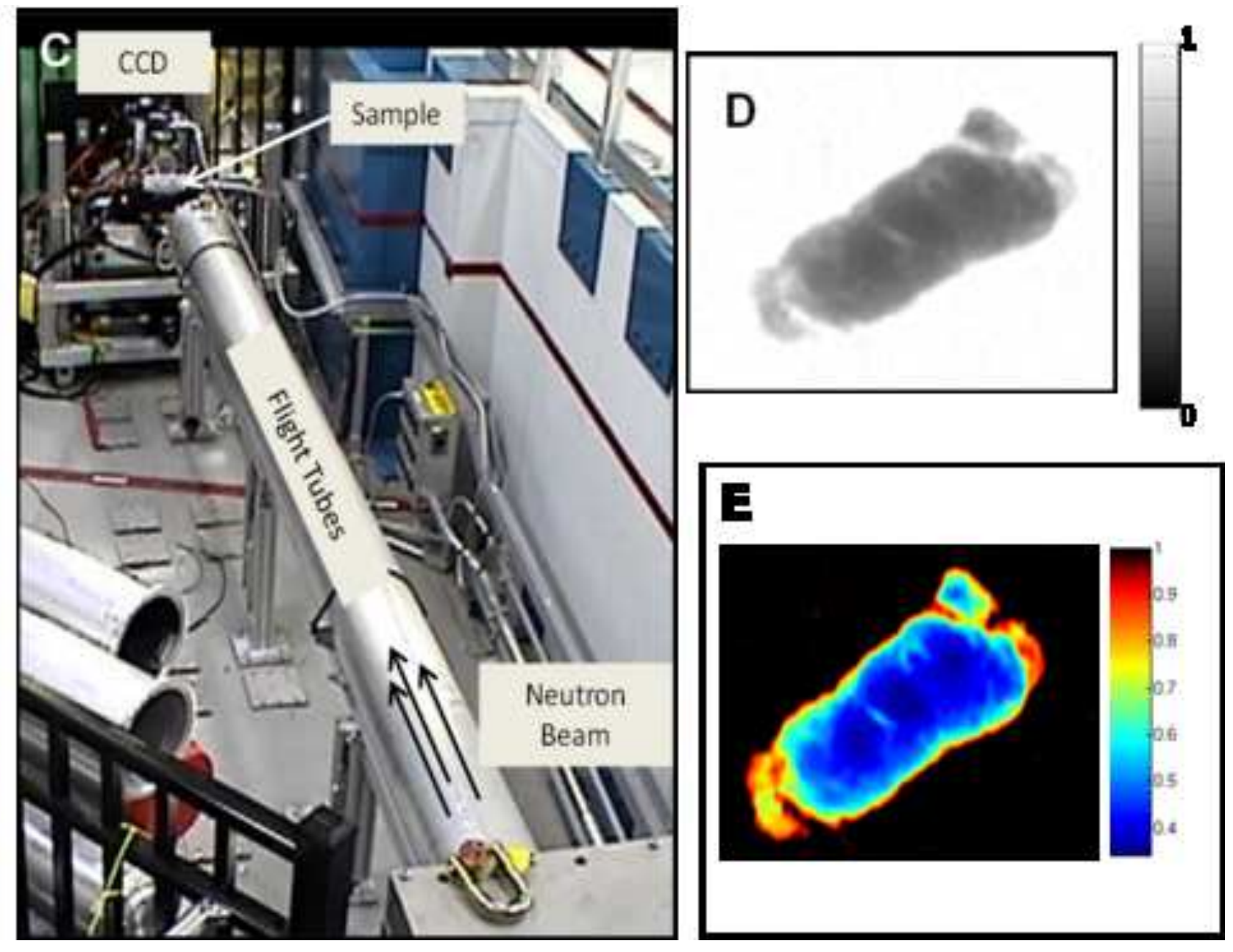

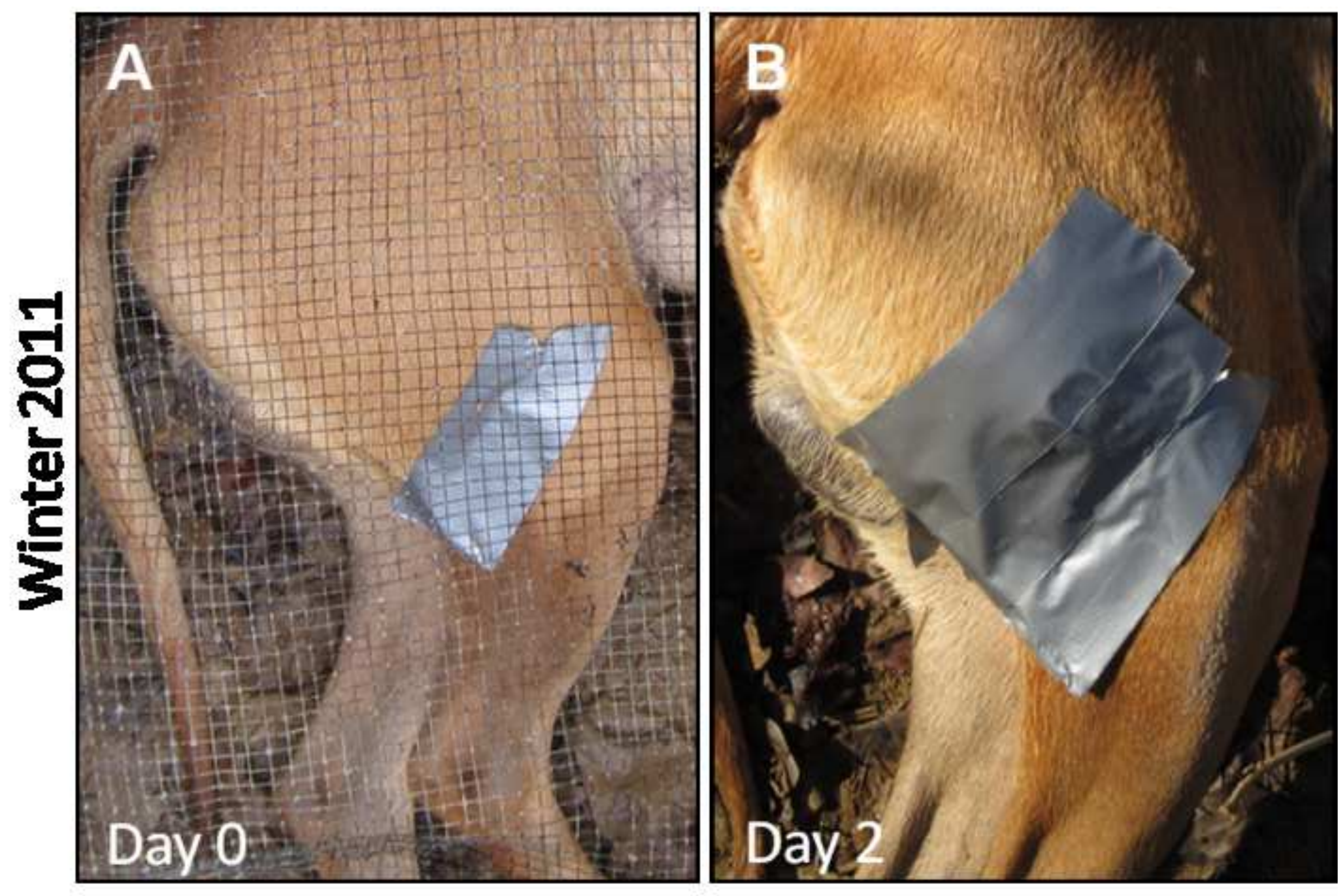
Figure
Click here to download high resolution image
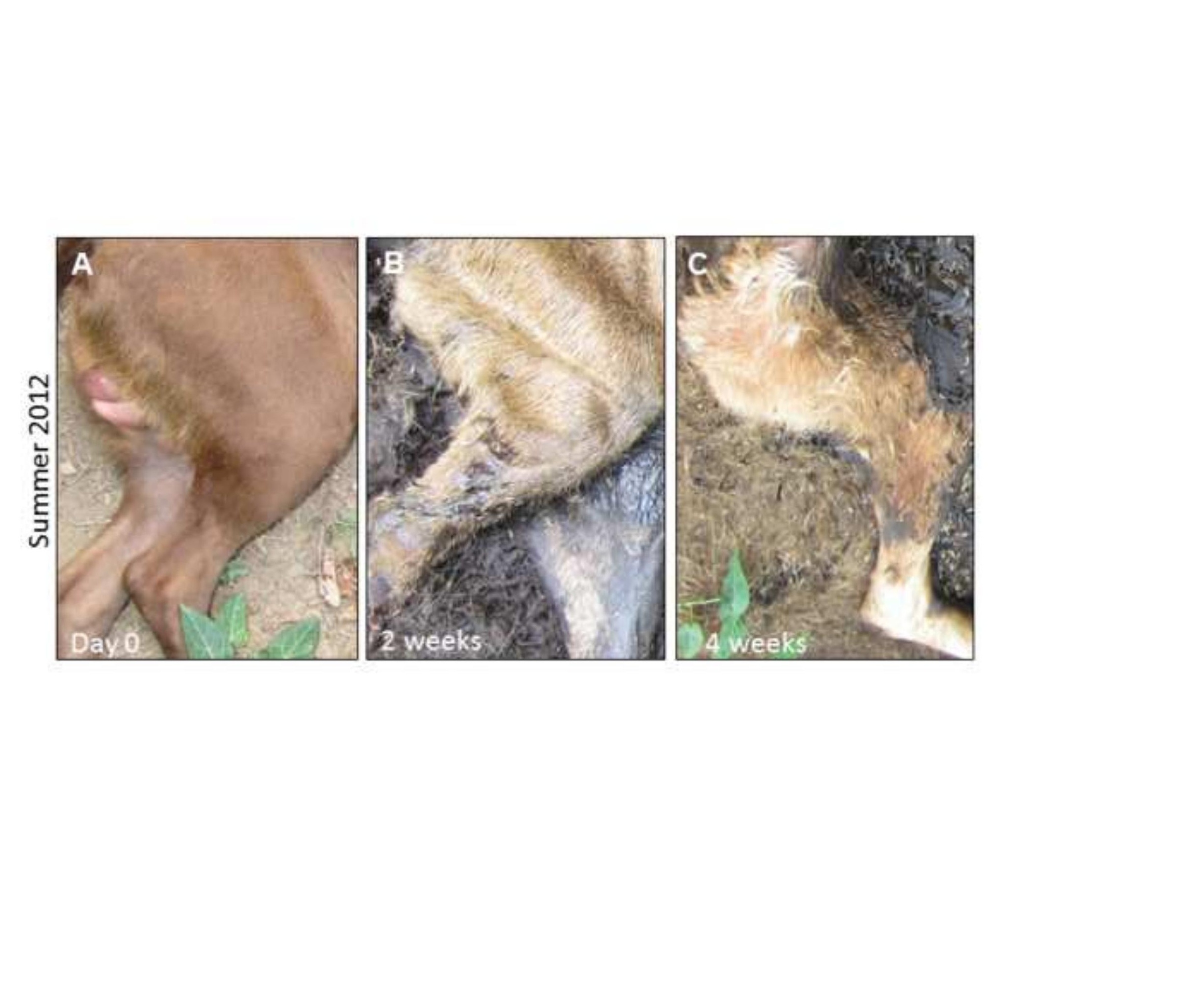

西

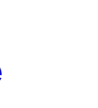

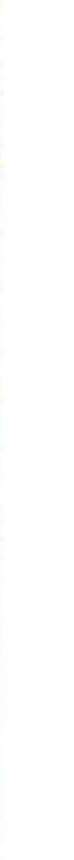
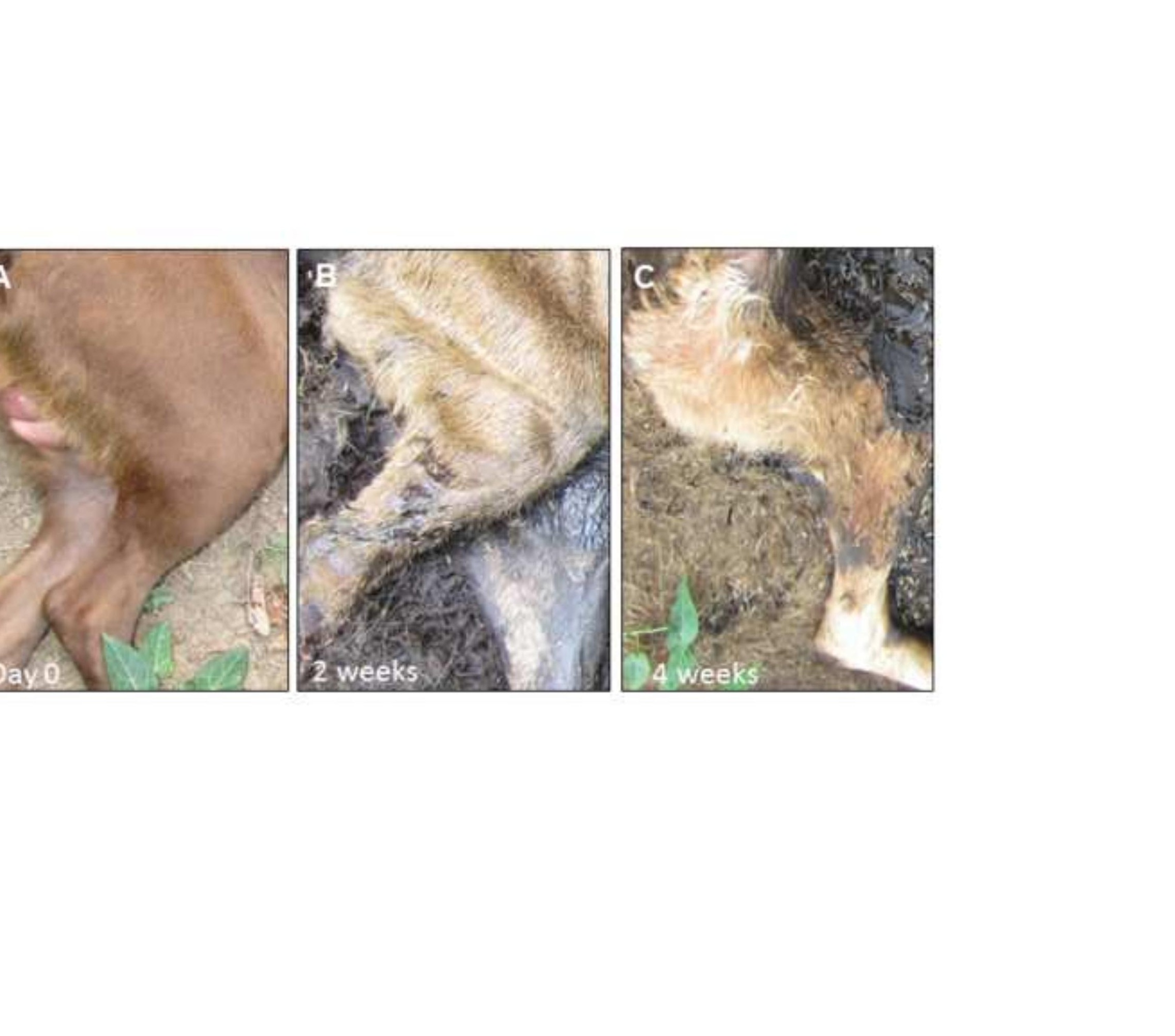

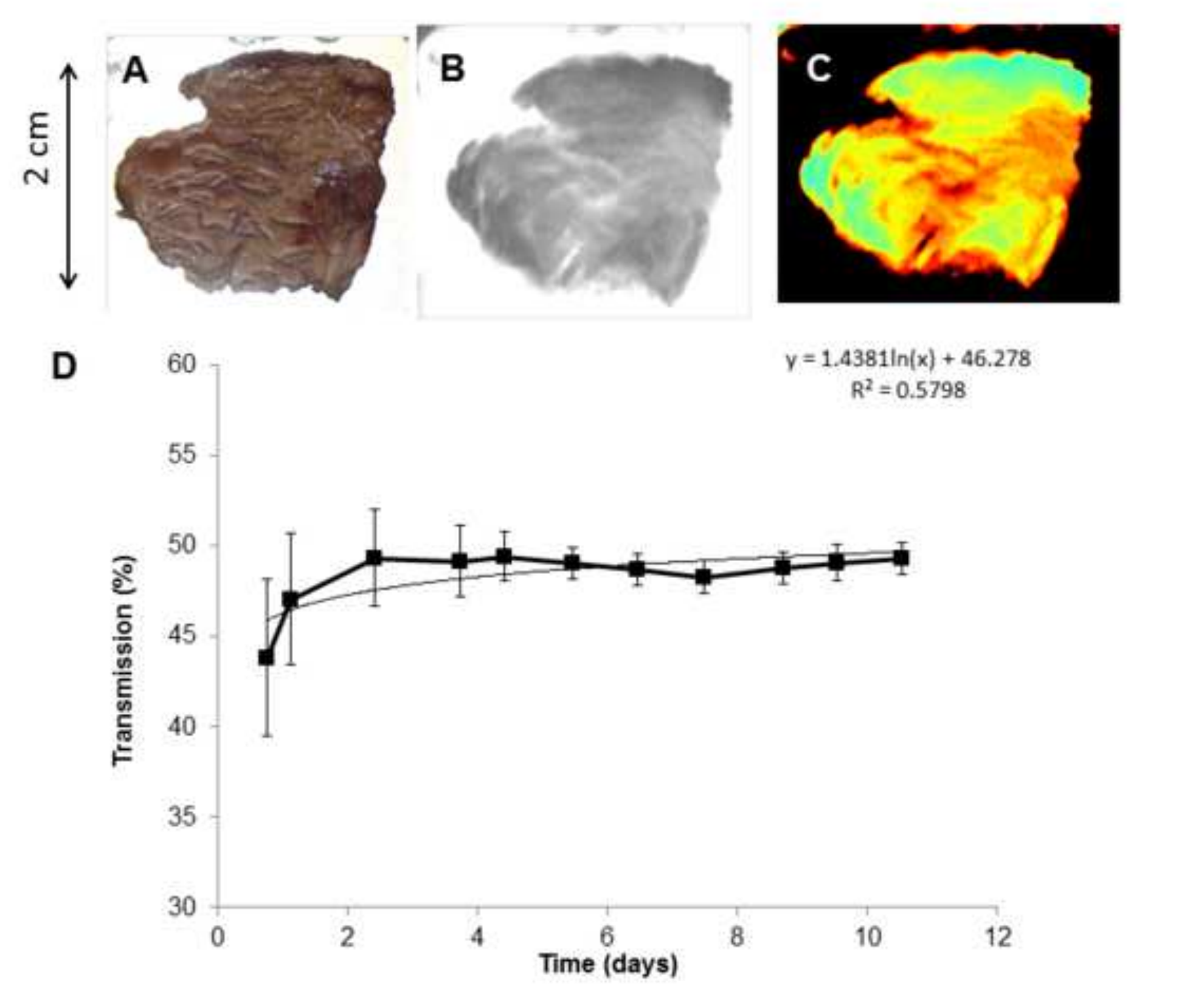
Figure
Click here to download high resolution image
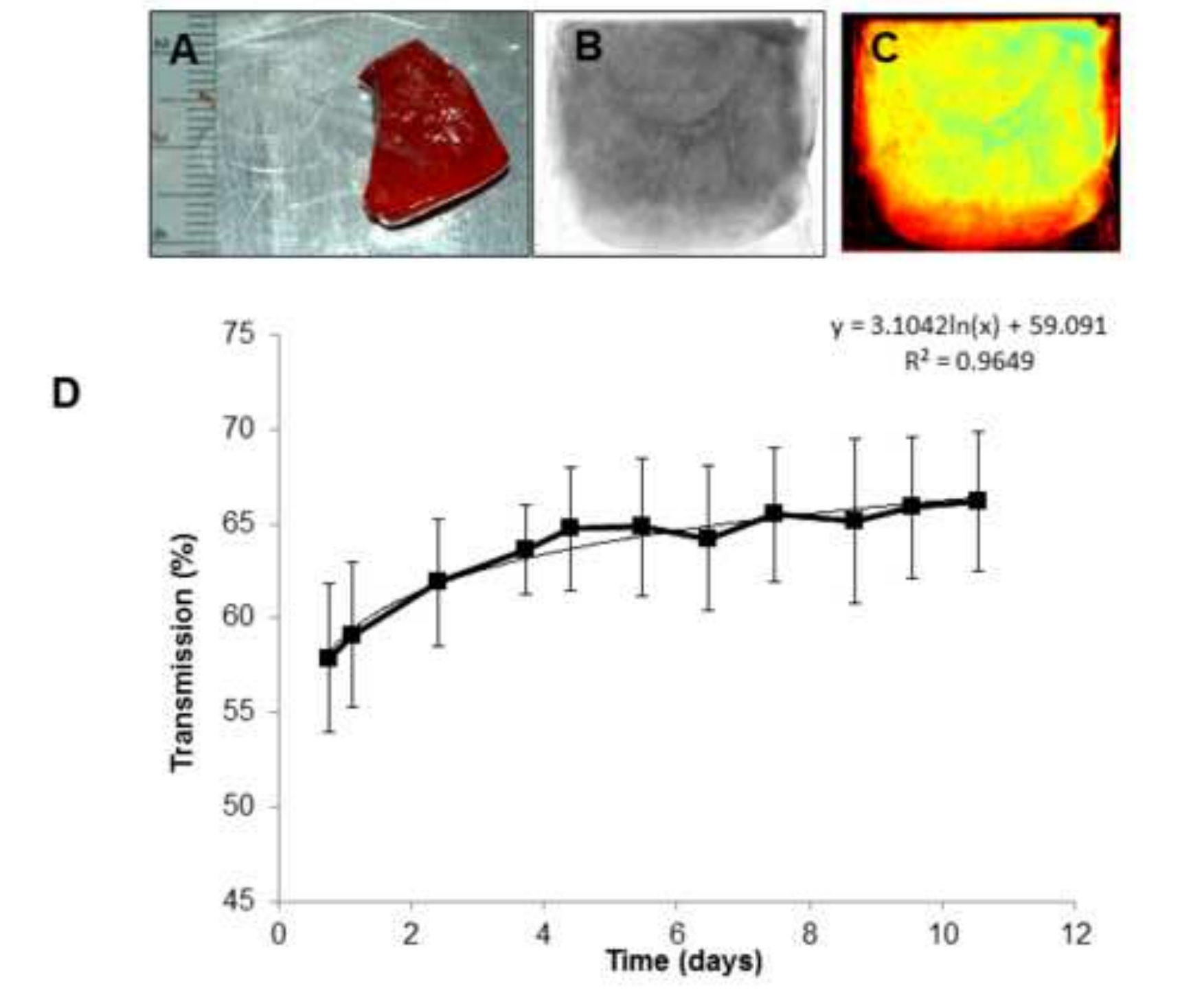

(

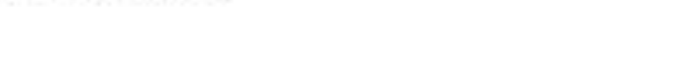

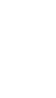
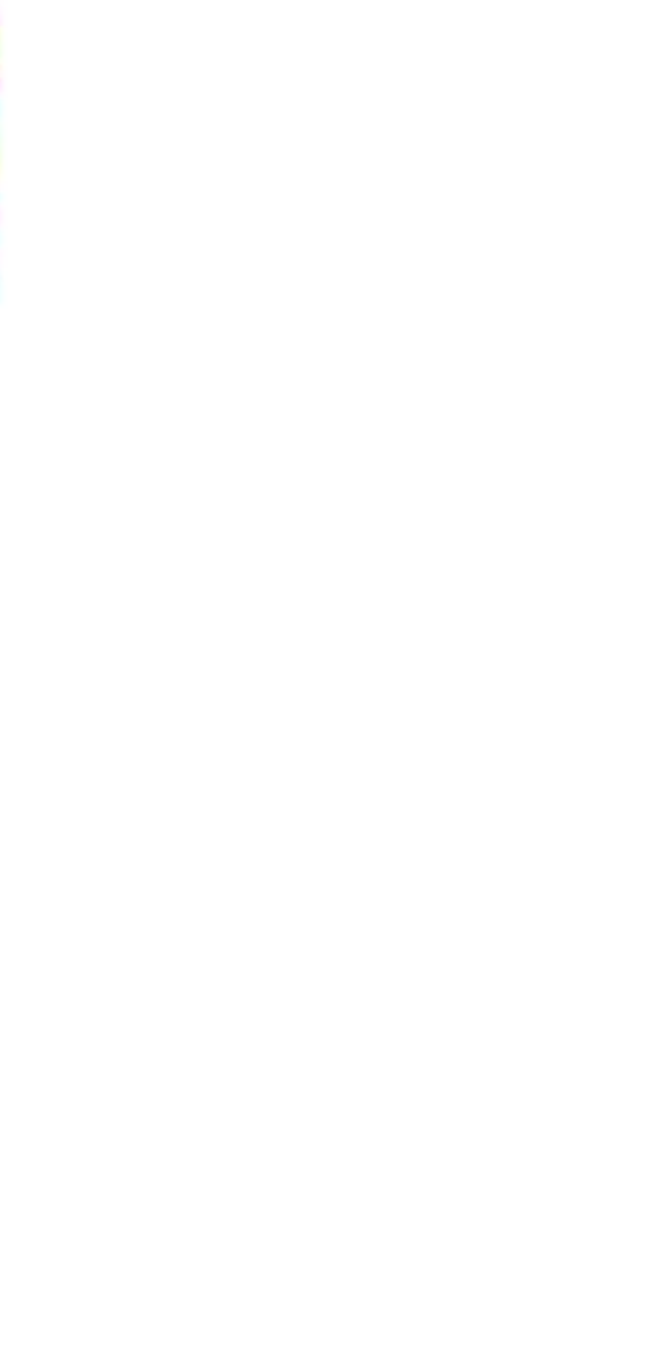

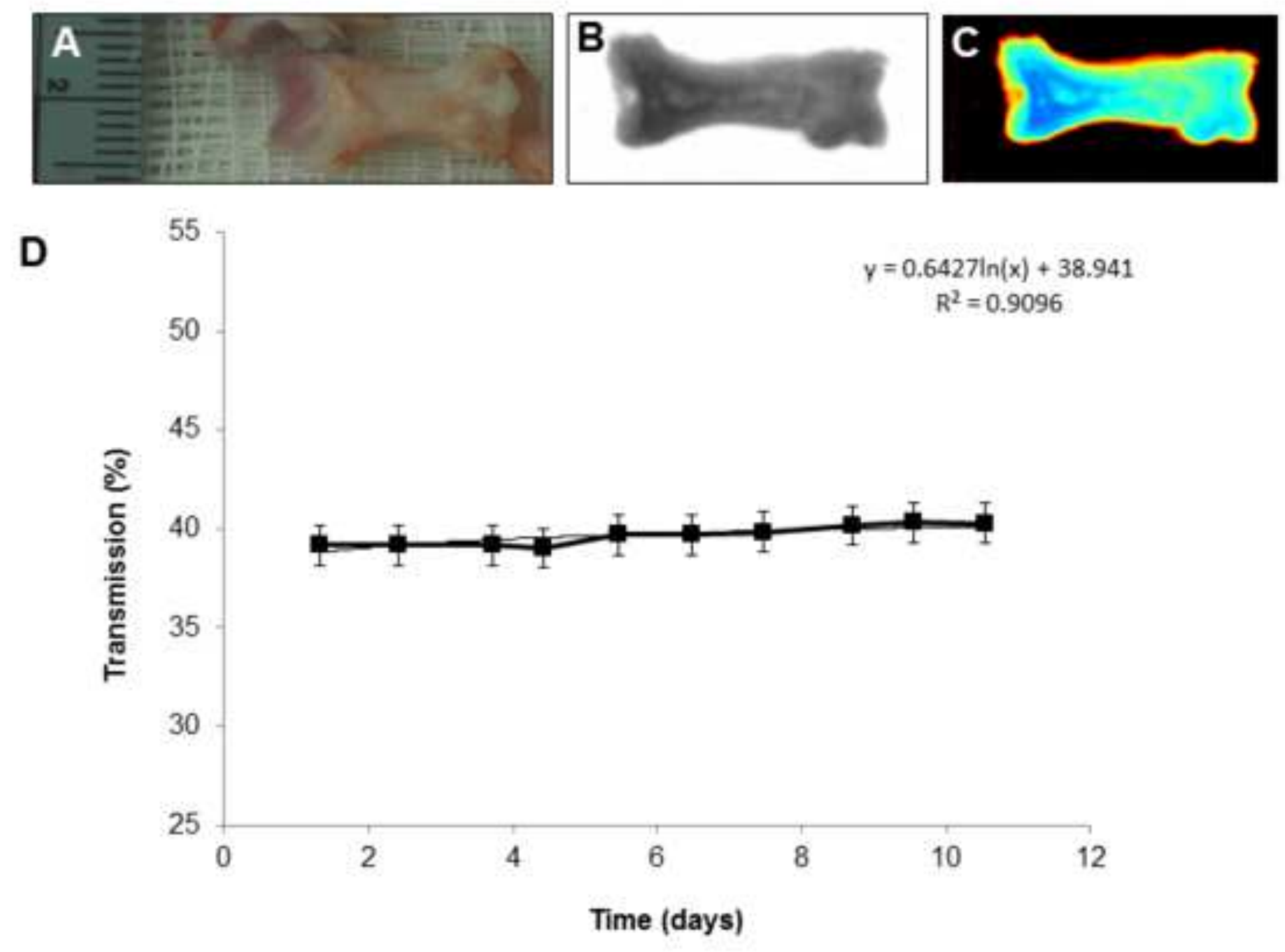

D 
Click here to download high resolution image

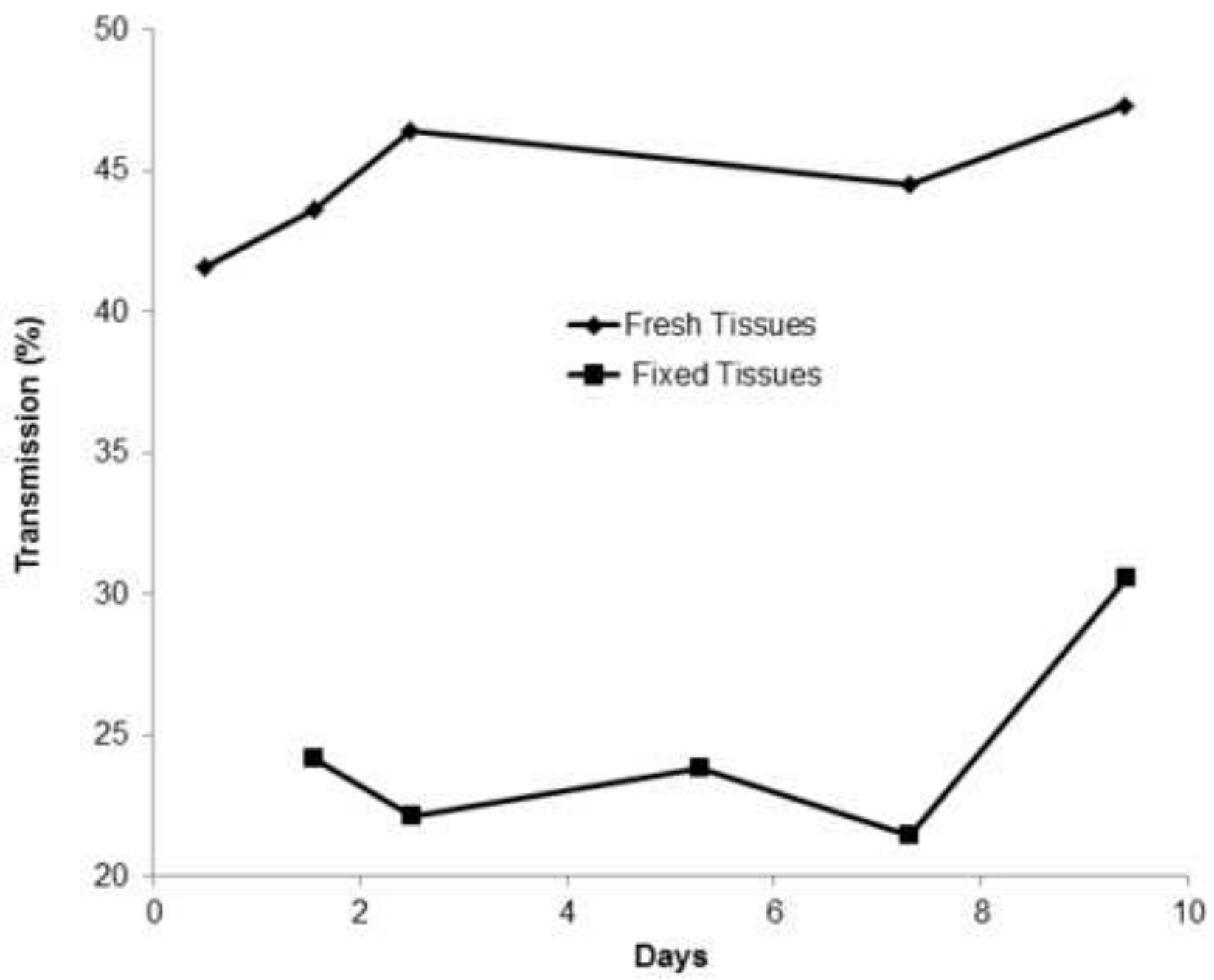


Click here to download high resolution image

A
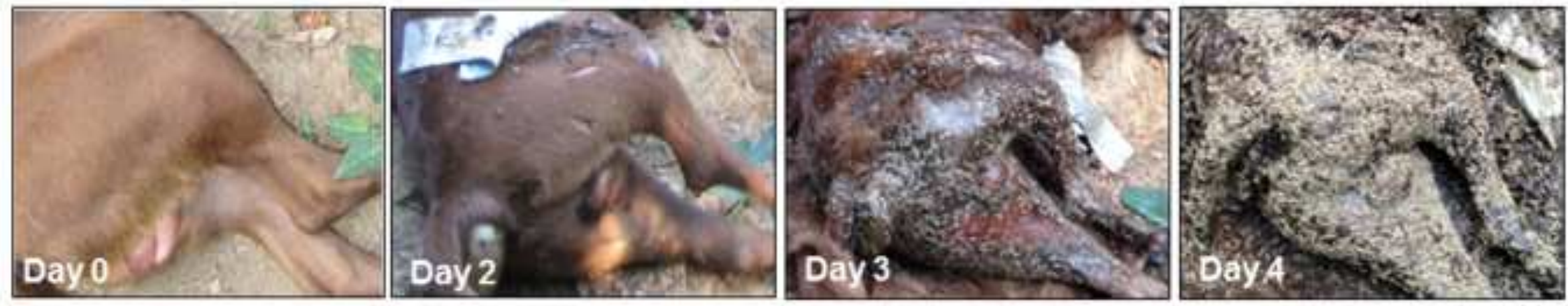

B
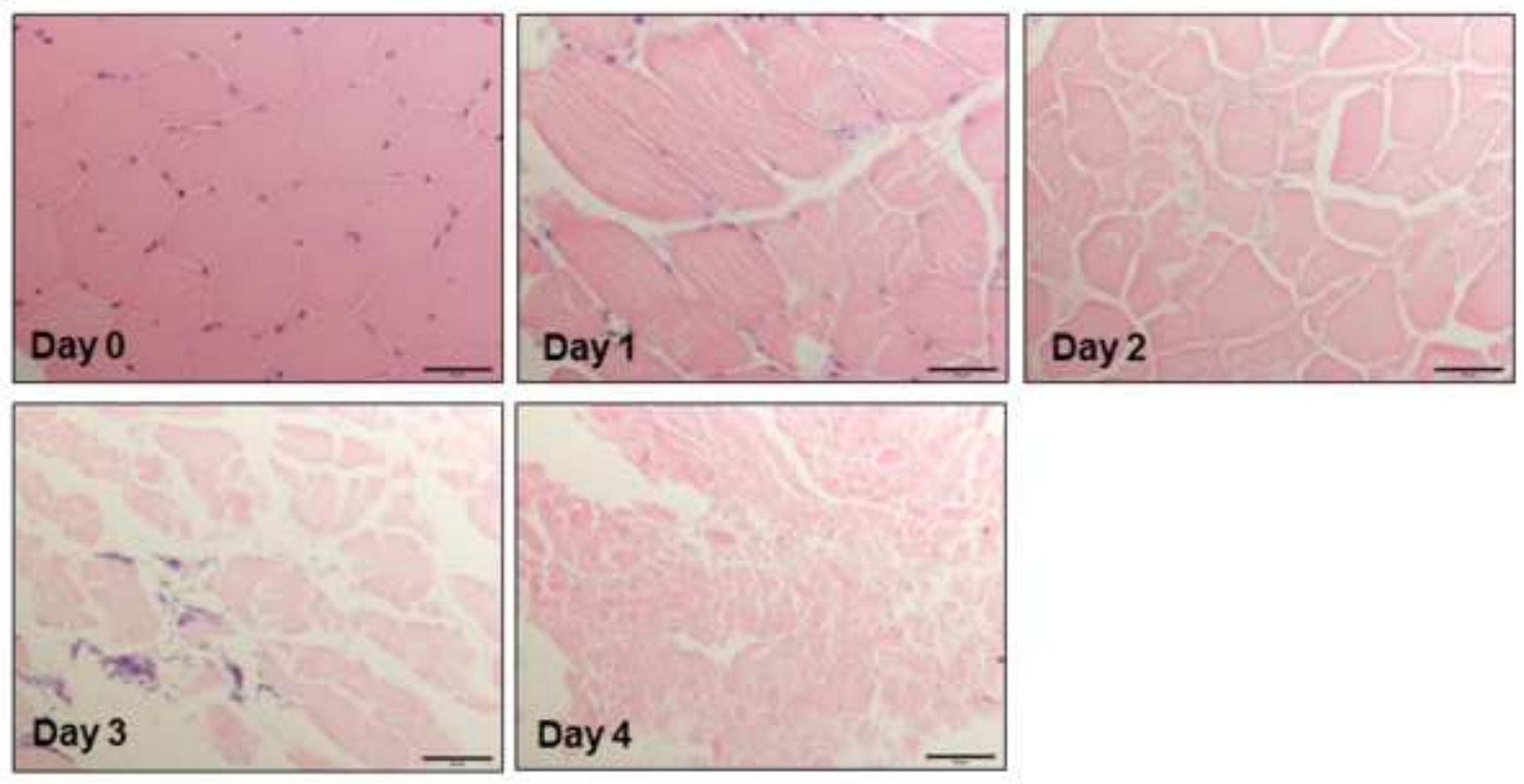
Click here to download high resolution image

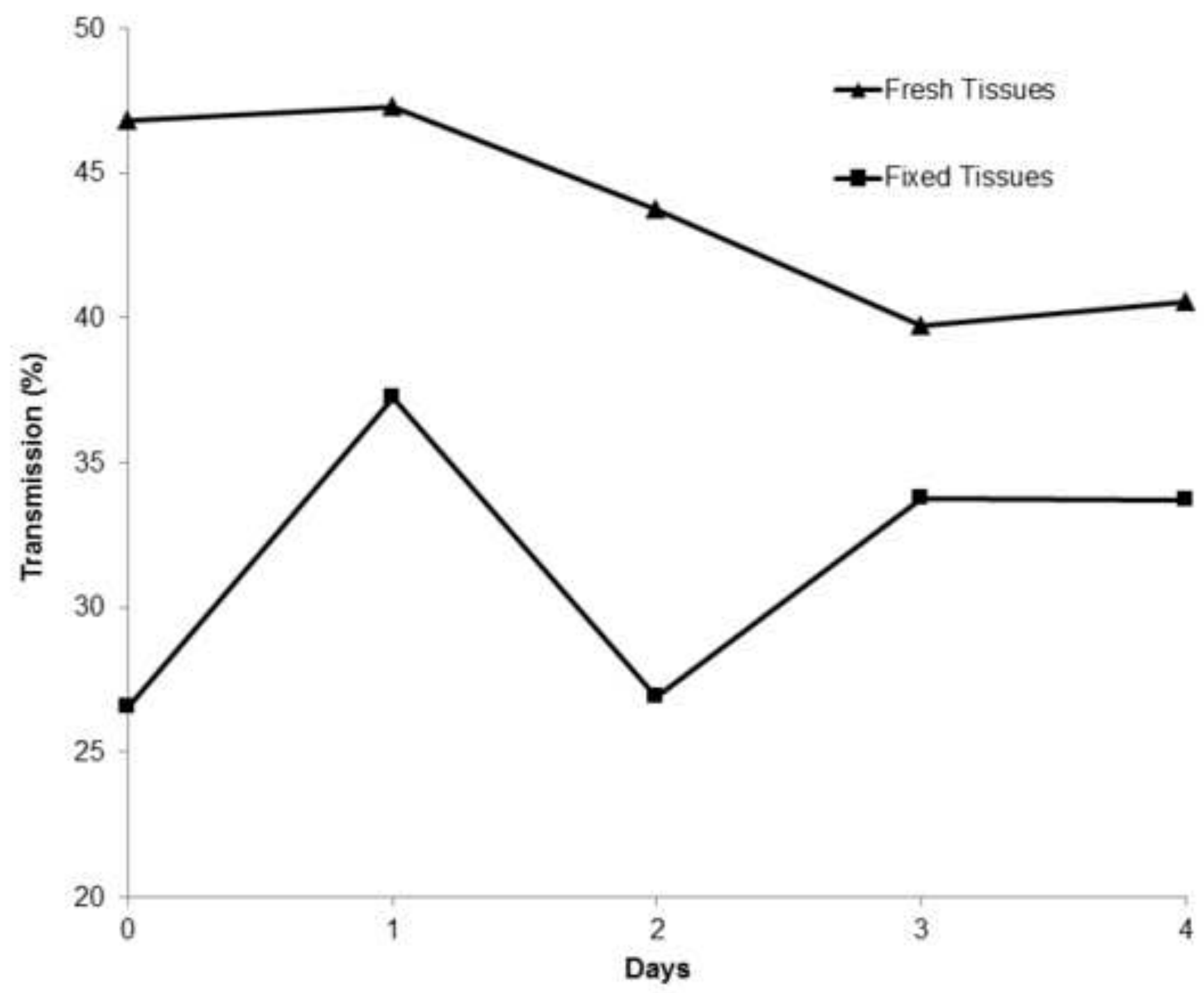




\begin{tabular}{|l|c|l|l|l|}
\hline Experiment & Dog \# & Date of placement at the ARF & Photographs & Dates of tissue extraction \\
\hline Winter 2011 & 1 & $\begin{array}{l}\text { Day 0 (December 7, 2011) or the first } \\
\text { day of the neutron radiographs }\end{array}$ & Day 0 and Day 2 & $\begin{array}{l}\text { First day and subsequently every } \\
\text { day to ten days }\end{array}$ \\
\hline
\end{tabular}

\begin{tabular}{|c|c|c|c|c|}
\hline Experiment & Dog \# & Date of placement at the ARF & Photographs & Dates of tissue extraction \\
\hline $\begin{array}{l}\text { Summer } \\
2012\end{array}$ & 1 & $\begin{array}{l}\text { Day }-41 \text { (six weeks prior to the first } \\
\text { neutron radiographs) }\end{array}$ & $\begin{array}{l}\text { None, cadaver } \\
\text { was completely } \\
\text { decomposed (no } \\
\text { tissue left) }\end{array}$ & $\mathrm{N} / \mathrm{A}$ \\
\hline $\begin{array}{l}\text { Summer } \\
2012\end{array}$ & 2 & $\begin{array}{l}\text { Day - } 27 \text { (four weeks prior to the first } \\
\text { neutron radiographs) }\end{array}$ & $\begin{array}{l}\text { Photograph } \\
\text { taken after } 4 \\
\text { weeks of } \\
\text { decomposition }\end{array}$ & $\mathrm{N} / \mathrm{A}$ \\
\hline $\begin{array}{l}\text { Summer } \\
2012\end{array}$ & 3 & $\begin{array}{l}\text { Day - } 13 \text { (two weeks prior to the first } \\
\text { neutron radiographs) }\end{array}$ & $\begin{array}{l}\text { Photograph } \\
\text { taken after } 2 \\
\text { weeks of } \\
\text { decomposition }\end{array}$ & N/A \\
\hline $\begin{array}{l}\text { Summer } \\
2012\end{array}$ & 4 & $\begin{array}{l}\text { Day } 0 \text { (June } 18,2012 \text { ) or the first day } \\
\text { of the neutron radiographs }\end{array}$ & $\begin{array}{l}\text { Days } 0,2,3 \text { and } \\
4\end{array}$ & Days $0,1,2,3$, and 4 \\
\hline
\end{tabular}




\begin{tabular}{|c|c|c|c|c|c|c|c|}
\hline \multicolumn{8}{|c|}{ Winter 2011} \\
\hline Day & $\begin{array}{c}\text { Solar } \\
(\mathrm{MJ} / \mathrm{m} 2)\end{array}$ & $\begin{array}{l}\text { Rain } \\
(\mathrm{mm})\end{array}$ & $\begin{array}{l}\text { Humidity } \\
(\%)\end{array}$ & $\begin{array}{c}\text { AirTemp } \\
\text { (9C) }\end{array}$ & $\begin{array}{l}\text { Soil Temp, } 15 \\
\text { cm depth } \\
\text { (9C) }\end{array}$ & $\begin{array}{l}\text { Air HighTemp } \\
\text { (9C) }\end{array}$ & $\begin{array}{c}\text { Air LowTemp } \\
\text { (9C) }\end{array}$ \\
\hline Day 0 & 1.25 & 5.64 & 86.20 & 5.08 & 12.60 & 9.94 & 1.62 \\
\hline Day 1 & 10.51 & 0.63 & 71.50 & 2.48 & 9.96 & 9.27 & -1.44 \\
\hline Day 2 & 10.02 & 0.31 & 74.60 & 3.71 & 9.63 & 11.06 & -2.18 \\
\hline Day 3 & 6.84 & 0.00 & 64.22 & 3.03 & 9.31 & 7.27 & 0.29 \\
\hline Day 4 & 10.82 & 0.00 & 63.86 & 2.56 & 8.27 & 10.46 & -2.31 \\
\hline Day 5 & 7.07 & 0.00 & 60.22 & 6.60 & 9.15 & 12.00 & 1.02 \\
\hline Day 6 & 3.96 & 0.00 & 75.10 & 9.50 & 10.91 & 13.79 & 7.15 \\
\hline Day 7 & 9.09 & 0.00 & 79.20 & 11.26 & N.D. & 19.57 & 6.35 \\
\hline Day 8 & 3.53 & 1.88 & 80.60 & 13.17 & N.D. & 18.52 & 6.82 \\
\hline $\begin{array}{c}\text { Average over } \\
\text { study }\end{array}$ & 7.01 & 0.94 & 72.83 & 6.38 & 9.98 & 12.43 & 1.92 \\
\hline
\end{tabular}




\begin{tabular}{|c|c|c|c|c|c|c|c|}
\hline \multicolumn{8}{|c|}{ Summer 2012} \\
\hline Day & Solar $(\mathrm{M} / \mathrm{m} 2]$ & Rain (mm) & Humidity (ss) & AirTemp ( $\left.{ }^{2} \mathrm{C}\right)$ & $\begin{array}{c}\text { Soil Temp, } 15 \mathrm{~cm} \\
\text { depth }(2 \mathrm{C})\end{array}$ & Air HighTemp $\left({ }^{\circ} \mathrm{C}\right)$ & Air LowTemp $\left({ }^{\circ} \mathrm{C}\right)$ \\
\hline Day -41 & 15.63 & 0.31 & 70.30 & 22.58 & 25.01 & 28.21 & 19.05 \\
\hline Day -40 & 12.09 & 0.31 & 63.47 & 19.19 & 24.26 & 22.70 & 14.34 \\
\hline Day -39 & 26.57 & 0.00 & 52.62 & 16.83 & 22.78 & 23.49 & 9.88 \\
\hline Day-38 & 26.48 & 0.00 & 52.26 & 17.41 & 22.66 & 26.02 & 9.08 \\
\hline Day -37 & 12.86 & 0.00 & 65.84 & 18.34 & 22.66 & 25.69 & 13.74 \\
\hline Day-36 & 6.10 & 13.15 & 86.40 & 17.44 & 22.34 & 19.19 & 16.13 \\
\hline Day - 35 & 13.18 & 21.60 & 82.00 & 18.82 & 21.65 & 25.02 & 15.53 \\
\hline Day-34 & 19.21 & 0.00 & 68.48 & 20.35 & 22.54 & 26.28 & 15.41 \\
\hline Day-33 & 21.80 & 0.00 & 67,08 & 20.14 & 22.99 & 28.15 & 13.55 \\
\hline Day -32 & 26.08 & 0.00 & 63.07 & 21.42 & 23.38 & 29.75 & 13.74 \\
\hline Day-31 & 2130 & 0.00 & 67.25 & 21.84 & 24.25 & 29.62 & 15.81 \\
\hline Day -30 & 24.25 & 0.00 & 67.67 & 22.35 & 24.89 & 29.41 & 16.47 \\
\hline Day-29 & 25.95 & 0.00 & 63.79 & 22.71 & 25.46 & 29.48 & 16.74 \\
\hline Day -28 & 15.80 & 5.32 & 76.50 & 20.28 & 25.24 & 29.00 & 16.41 \\
\hline Day-27 & 9.04 & 6.89 & 81.30 & 19.21 & 24.24 & 24.22 & 17.20 \\
\hline Day -26 & 15.79 & 10.65 & 81.70 & 20.09 & 23.61 & 28.08 & 17.00 \\
\hline Day-25 & 24.61 & 0.00 & 68.32 & 22.37 & 24.69 & 30.80 & 16.99 \\
\hline Day -24 & 25.87 & 0.00 & 65.92 & 24.08 & 25.60 & 32.79 & 16.41 \\
\hline Day-23 & 24.62 & 0.00 & 67.04 & 25.34 & 26.62 & 33.26 & 18.79 \\
\hline Day -22 & 24.61 & 0.00 & 66.16 & 26.02 & 27.37 & 33.59 & 19.86 \\
\hline Day-21 & 25.49 & 0.00 & 61.29 & 26.63 & 27.84 & 34.27 & 19.86 \\
\hline Day -20 & 19.57 & 0.00 & 69.12 & 24.66 & 27.97 & 32.19 & 20.12 \\
\hline Day $=19$ & 27.19 & 0.00 & 59.16 & 25.34 & 27.85 & 33.20 & 19.26 \\
\hline Day-18 & 21.57 & 8.45 & 64,96 & 23.22 & 27.78 & 31.59 & 17.27 \\
\hline Day $=17$ & 14.59 & 13.15 & 75.50 & 19.41 & 26.26 & 22.83 & 15.20 \\
\hline Day-16 & 25.45 & 0.00 & 59.39 & 17.11 & 24.60 & 23.55 & 10.74 \\
\hline Day -15 & 23.29 & 0.00 & 62.66 & 20.88 & 24.82 & 29.21 & 12.82 \\
\hline Day-14 & 15.52 & 0.00 & 64.68 & 22.70 & 25.62 & 29.75 & 18.79 \\
\hline Day -13 & 23.40 & 5.64 & 61.70 & 21.05 & 25.39 & 26.81 & 16.13 \\
\hline Day-12 & 22.61 & 0.00 & 54.33 & 20.95 & 25.00 & 27.62 & 14.27 \\
\hline Day -11 & 23.74 & 0.00 & 55.20 & 21.74 & 25.32 & 29.08 & 14.87 \\
\hline Day-10 & 27.96 & 0.00 & 51.00 & 22.23 & 25.57 & 29.48 & 15.41 \\
\hline Day -9 & 22.51 & 0.00 & 60.82 & 23.43 & 25.59 & 30.46 & 16.47 \\
\hline$D_{y y}-8$ & 13.22 & 0.31 & 71.30 & 22.77 & 26.29 & 27.81 & 20.05 \\
\hline Day -7 & 13.31 & 3.44 & 78.10 & 22.85 & 25.27 & 28.28 & 19.72 \\
\hline$D_{y y}-6$ & 16.73 & 2.51 & 75.60 & 24.32 & 25.65 & 29.15 & 20.72 \\
\hline Day -5 & 23.62 & 0.00 & 60.39 & 24.64 & 26.03 & 31.27 & 17.99 \\
\hline Day 4 & 22.10 & 0.00 & 61.67 & 24.23 & 26.22 & 33.33 & 18.33 \\
\hline Day -3 & 23.35 & 0.00 & 64,04 & 24.89 & 26.72 & 32.33 & 18.86 \\
\hline Dyy -2 & 18.36 & 3.13 & 67.83 & 24.11 & 27.18 & 29.22 & 20.12 \\
\hline Day -1 & 2133 & 0.00 & 64.48 & 24.37 & 26.43 & 30.73 & 19.72 \\
\hline Day 0 & 27.10 & 0.00 & 58.19 & 25.83 & 27.15 & 32.66 & 18.73 \\
\hline Day 1 & 25.52 & 0.00 & 58.76 & 26.01 & 27.59 & 34.25 & 18.66 \\
\hline Day 2 & 24.87 & 0.00 & 57.00 & 27.35 & 28.57 & 34.19 & 20.65 \\
\hline Day 3 & 23.77 & 2.82 & 61.09 & 27.39 & 29.37 & 34.92 & 21.12 \\
\hline Day 4 & 23.83 & 0.31 & 62.79 & 27.23 & 29.46 & 35.32 & 21.65 \\
\hline Average over study & 20.91 & 2.13 & 65.61 & 22.44 & 25.52 & 29.31 & 16.95 \\
\hline
\end{tabular}




\begin{tabular}{|c|c|c|c|c|c|c|c|}
\hline Tissue Type & $\mathbf{R}^{2}$ & $\Delta$ transmission & STD & SE & Estimated PMI (h) & PMI (h) & Accuracy $(\%)$ \\
\hline Bones & 0.91 & 0.002 & 0.002 & 0.0006 & 12.6 & 18 & 70.0 \\
\hline Muscles & 0.58 & 0.008 & 0.011 & 0.0034 & 0.25 & 18 & 1.4 \\
\hline Lungs & 0.96 & 1.036 & 0.790 & 0.2495 & 11.5 & 18 & 63.9 \\
\hline
\end{tabular}

